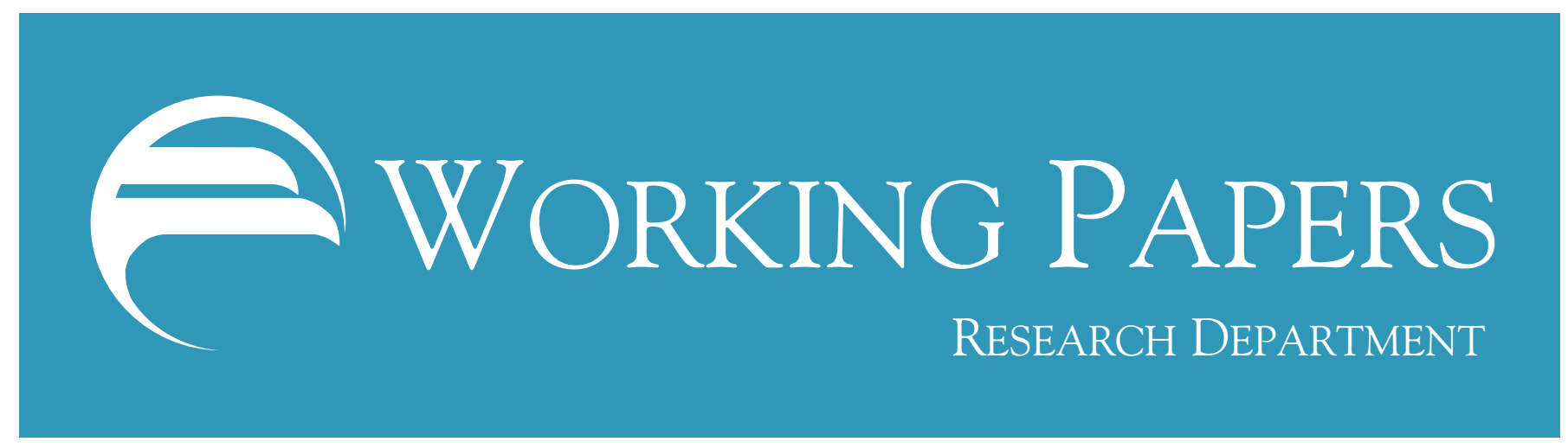

\title{
WORKING PAPER NO. 03-6 \\ WHAT IS THE VALUE OF RECOURSE TO ASSET BACKED SECURITIES? A CLINICAL STUDY OF CREDIT CARD BANKS
}

Eric J. Higgins

Kansas State University

Joseph R. Mason

Drexel University and

Visiting Scholar, Federal Reserve Bank of Philadelphia

April 2003

\section{FEDERAL ReSERVE BANK OF PHILADELPHIA}

Ten Independence Mall, Philadelphia, PA 19106-1574• (215) 574-6428•www.phil.frb.org 


\section{What IS THE VALUE OF RECOURSE TO ASSET BACKED SECURITIES? A Clinical STUdY OF CREDit CARd BANKS}

by

Eric J. Higgins

and

Joseph R. Mason

April 2003

Higgins: Kansas State University. Mason: Drexel University, Federal Reserve Bank of Philadelphia, and Wharton Financial Institutions Center. The authors thank Mitch Berlin, Peter Burns, Charles Calomiris, Loretta Mester, Jim Moser, and Ronald Watson for comments and criticism on earlier drafts. The authors also thank Drexel University's Bennett S. LeBow College of Business for a Summer Research Grant and the Federal Reserve Bank of Philadelphia's Payment Cards Center for continuing support. An earlier draft of this paper was presented at the 2002 Financial Management Association Meetings and the 2002 Eastern Finance Association Meetings. The views expressed in this paper are those of the authors and do not necessarily represent the views of the Federal Reserve Bank of Philadelphia or the Federal Reserve System. Please address all correspondence to Joseph R. Mason, LeBow College of Business, Drexel University, 3141 Chestnut Street, Philadelphia, PA 19104. (215) 895-2944, joe.mason@drexel.edu. 


\begin{abstract}
The present paper uses data from revolving credit card securitizations to show that, conditional on being in a position where implicit recourse has become necessary and actually providing that recourse, recourse to securitized debt may benefit short-and longterm stock returns, and long-term operating performance of sponsors. The paper suggests that this result may come about because those sponsors providing the recourse do not seem to be extreme default or insolvency risks. However, sponsors providing recourse do experience an abnormal delay in their normal issuance cycle around the event. Hence, it appears that the asset-backed securities market is like the commercial paper market, where a firm's ability to issue is directly correlated with credit quality. Therefore, although in violation of regulatory guidelines and FASB140, recourse may have beneficial effects for sponsors by revealing that the shocks that made recourse necessary are transitory.
\end{abstract}


Commercial banks have a strong incentive to sell assets in order to increase liquidity, reduce interest rate risk, and avoid burdensome regulations. However, most bank assets are high asymmetric information financial instruments and, as a result, are fundamentally illiquid. Hence, commercial banks have become increasingly reliant upon securitization as a means of selling assets.

Business strategies that revolve around securitization are accompanied by a host of incentive conflicts. At various times during the 1990s, securitization has been associated with financial difficulties arising from fictitious financial ratios (gain-on-sale provisions), understated leverage (Enron), and hidden risks (Enron, PNC, and other commercial banks). The present paper concerns itself with the last of these, that is, the propensity for securitizations to mask risks to the sponsor, ${ }^{1}$ whether the sponsor is a bank originating loans or a nonbank firm posting other collateral for securitization (Calomiris and Mason 2003; Jones 2000).

Risks often remain with the sponsor because securitization - and the removal of assets from the sponsor's balance sheet - relies on a "true sale" to a legally remote third party. If the assets are not truly sold or the sale is not to a legally defined third party, the assets must be reported on the sponsor's balance sheet. One important condition that determines whether a true sale has taken place is whether the sale agreement provides recourse, or performance guarantees, to the buyer. If recourse terms are present, the assets pose a contingent risk to the seller which, under FASB140, prohibits the removal of the assets from the seller's balance sheet.

While few loan sales contracts contain explicit terms that provide recourse, many loan sales (particularly those involving revolving collateral like credit card loans) hinge upon an implicit understanding that recourse may be provided by the sponsor. Such understandings exist

\footnotetext{
${ }^{1}$ The sponsor originates the assets and sells them to a bankruptcy-remote third-party trust that funds the purchase by issuing asset-backed securities.
} 
because sponsors wish to maintain their reputations for consistent credit quality over repeated sales (while still taking advantage of the ability, under a true sale, to remove the assets from the balance sheet). Losing a good reputation (and the ability to sell loans economically) may expose the sponsor to decreased liquidity, increased interest rate risk, and burdensome regulatory supervision.

By providing recourse in cases where none is explicitly required, the sponsor demonstrates the presence of de facto recourse and therefore previously unreported contingent liabilities. The present paper examines the effects of these revelations on the sponsor. On the face of it, one might expect that revealing previously unreported contingent liabilities could heighten asymmetric information about firm conditions, resulting in poor short- and long-term stock price performance, poor long-term financial performance, and reduced proceeds from subsequent loan sales. However, we find that, conditional on being in a position where honoring implicit recourse has become necessary and conditional on actually providing that recourse, the sponsors, on average, exhibit improved short- and long-term stock price performance, improved long-term financial performance, and similar proceeds from subsequent loan sales.

The rest of the paper proceeds by describing in Section I the choice of credit card banks for this study of recourse, the sample of credit card banks used, the recourse events that have taken place in the history of credit card securitization, and the recourse credit card bank sample analyzed throughout the paper. Section II examines short-term stock price effects around recourse announcements for recourse announcing firms and non-recourse announcing firms. Section III examines long-term stock price and financial performance around recourse announcements. Section IV examines the riskiness of sponsors that provide recourse. Section V 
examines subsequent loan sale proceeds and provisions around recourse announcements. Section VI summarizes and concludes.

\section{Credit Card Banks and Implicit Recourse}

\section{A. Why credit card banks?}

There are four key stages of the securitization process. ${ }^{2}$ First, the sponsor sells a collateral pool to a bankruptcy-remote third-party trust or special purpose entity (SPE). In this step, the sale to the bankruptcy-remote third-party - the "true sale" - is crucial to removing the collateral from the sponsor's balance sheet in accordance with generally accepted accounting principles (GAAP - FASB 140) and regulatory accounting principles (RAP). Both GAAP and RAP stipulate that in the event a true sale is deemed to have not occurred, that is, if the third party is not bankruptcy remote or if the sponsor maintains control over the assets, the collateral must revert to the sponsor's balance sheet.

Second, the SPE hires an investment bank to engineer tranches of debt securities and underwrite the sale of the securities. Before the tranche structure is complete, it is stress-tested by one or more ratings agencies to certify the investment quality of the securities. After certification is complete the investment bank sells the issue to investors.

Third, the securitization enters the revolving stage, lasting anywhere from two to 10 years (sometimes more in the case of collateral other than credit cards). During this period a constant pool size is maintained by the SPE, from which interest and principal payments may be passed along to investors monthly. With short-term collateral like credit cards, principal collected during this stage is used to purchase additional receivables from the sponsor and replenish the investors' portfolio. Since the sponsor and SPE have a bankruptcy-remote third-party relationship, the

\footnotetext{
${ }^{2}$ For additional background, see the $A B C$ 's of Credit Card ABS and Moody's 1997.
} 
sponsor is expected to sell receivables to the SPE at par value, if not (higher) market value. Selling below par is usually taken as evidence that the sponsor is controlling the trust and hence a true sale has not in fact taken place. Under GAAP and RAP, therefore, the collateral should revert to the sponsor's balance sheet.

Last, the securitization enters the amortization phase. During the amortization phase principal payments are either accumulated into a pool that will be used to repay investor principal upon a stated date or distributed to investors with monthly coupon payments across a stipulated time period (usually one year). Amortization may occur as originally planned in the securities prospectus or earlier. The latter is referred to as early amortization. Early amortization is an investor remedy that is imposed if the collateral does not perform in a manner that could reasonably be expected to support payments of principal and interest to investors. Typical portfolio events that lead to early amortization in credit card securitizations are increased chargeoffs, decreased payment rates, and reduced portfolio yield. The purpose of early amortization is to repay investors before these events lead to loss of principal.

In the event of early amortization, the SPE will no longer be able to purchase new collateral from the sponsor. Hence the sponsor must either accept new collateral on-balancesheet or set up a new SPE to accept the collateral. Given the demonstrated instability of collateral performance, the latter will most likely be uneconomical. On the other hand, unless the sponsor can raise funds quickly via capital markets (which is again unlikely to be economical, given demonstrated instabilities in collateral performance), accepting new collateral on-balance-sheet may result in a substantially increased leverage, leading to reduced regulatory capital ratios and, potentially, regulatory insolvency. 
Our choice of credit card banks as the subject of our study is related to the securitization process described above. There are three main reasons for focusing on credit card banks. First, credit card securitizations are relatively simple structures, typically consisting of one or two tranches of investor securities accompanied by an underlying credit enhancement, i.e., monoline insurance coverage, overcollateralization, collateral invested amounts, and/or cash collateral accounts. In contrast, for instance, mortgage-backed securities routinely exceed 50 tranches and often include complex features like interest- and principal-only strips and more sophisticated credit enhancement structures.

Second, although all securitizations contain early amortization clauses, the difficulty of predicting payment rates and chargeoffs in revolving collateral makes those clauses critically important in credit card securitizations. Furthermore, the revolving structure also provides a convenient avenue for providing recourse by pricing replenishment sales to the SPE below market and/or par value.

Last, general purpose credit card (VISA and MasterCard) sponsors are required by their associations to be regulated financial institutions. Furthermore, the largest credit card loan sponsors in the US are commercial banks. Commercial banks are required to maintain an $8 \%$ capital-to-asset ratio or face regulatory action. Accepting new credit card loans on-balance-sheet during an early amortization may result in banks' violating the $8 \%$ capital ratio. Hence, with revolving collateral (and need for replenishment) and regulatory capital requirements, credit card banks have both the ability and the need to avoid early amortization by providing recourse to outstanding credit card securitizations. 


\section{B. Implicit recourse events at credit card banks}

Our data sets combine call report data on banks with Faulkner \& Gray data on the quantity of managed credit card receivables and securitizations, CRSP stock price data, Compustat financial data, Securities Data Corp. data on the structure and frequency of securitizations, and Lexis-Nexis news reports of recourse events affecting credit card securitizations.

Our search of Lexis-Nexis for the period 1987 (the year of the first credit card securitization) to 2001 turned up 17 discrete recourse events involving 10 credit card banks. We identified recourse events through news filings that reported "ratings affirmations" following a period of weak collateral pool performance. The news reports usually give some description of the reason for the affirmations. During the period 1987 to 2001, only two credit card securitizations entered early amortization without recourse. The associated sponsors, Republic Bank (DE) and Southeast Bank, both failed, although the securitizations repaid investors full principal in the early amortization process. Table 1 lists our set of recourse events, the bank names, the dates, the recourse actions taken, and the specific securities and/or pools involved. The set of banks in Table 1 makes up our recourse credit card bank sample.

The 10 banks identified as providing recourse are invariably large credit card banks. The minimum securitization size among these banks in 1996 is that of Tandy National Bank with $\$ 350$ million outstanding, and the maximum is that of Citicorp, with $\$ 25.9$ billion outstanding. The dollar amount of securitizations at recourse credit card banks averages $\$ 6.1$ billion, with a median of $\$ 3.5$ billion. The average percent of total credit card loans securitized among recourse credit card banks was $42 \%$, with a median of $45 \%$.

Credit card lending and securitization (and hence recourse) are important for the parent companies and banks in Table 1. To gauge the importance of credit card lending to the 
consolidated parent firm, Table 1 shows "managed (both on- and off-balance-sheet) credit card loans as a percent of consolidated parent company on-balance-sheet assets." These percentages range from 54\% for Sears Roebuck and Company to 5\% for First Union, with an average of 25\% and a median of $8 \%$. Hence, credit cards appear to be an important business line for these parent firms and bank holding companies. Surprisingly, measured by managed credit card loans as a percent of consolidated parent company on-balance-sheet assets, credit cards appear more important for non-bank firms than for the bank holding companies in Table 1. The non-bank firms (Sears, Household, AT\&T, and Tandy) average managed credit card loans as a percent of consolidated parent company on-balance-sheet assets of $43 \%$ and a median of $32 \%$, compared with an average managed credit card loans as a percent of consolidated parent company onbalance-sheet assets of $11 \%$ and a median of $5 \%$ for the bank holding companies (Citibank, Mercantile, FCC, Banc One, and First Union). ${ }^{3}$

These credit card operations are usually concentrated in one or two banks in the holding company. The column entitled "bank's credit card loans as percent of consolidated firm (BHC) credit card loans" illustrates that concentration. The non-bank firms in Table 1 own individual banks that form the basis for their credit card lending. Hence, those banks' credit card loans as percent of consolidated firm (or consolidated bank holding company) credit card loans is $100 \%$. Bank holding companies also usually concentrate their credit card operations in one or two bank charters that specialize in credit card lending and securitization. Even though First Union's credit cards are 5\% of its consolidated assets, they are primarily concentrated (99\%) in First Union, GA. Similarly, the preponderance of First Chicago's credit card loans (95\%) is held in First Chicago, DE. Even Citicorp maintains the majority of its credit card loans (72\%) in two charters, Citibank, SD, and Citibank, NV. Mercantile holds $51 \%$ of its credit card loans in its Hartford, IL,

\footnotetext{
${ }^{3}$ Financial and equity returns are unavailable for Prudential, since it is a non-public firm.
} 
charter. Only Banc One distributes its credit cards more widely through its banks, the largest individual exposure being $25 \%$ in its Dayton, $\mathrm{OH}$, charter.

In the event of early amortization, the charters described above are those that would be affected by the sudden accelerated on-balance-sheet loan growth. That potential growth can be gauged by “managed credit card loans as a percent of the credit card bank's (or banks') onbalance-sheet total assets" in Table 1. The largest exposure is at AT\&T, with securitizations totaling more than 265 times on-balance-sheet bank assets. Tandy comes in second, with securitizations totaling 39 times its on-balance-sheet assets. Sears securitizes about 17 times its on-balance-sheet assets, Mercantile 3 times, Banc One about 2 times, and Citibank and FCC about 1.8 times. Prudential and First Union sell the least, securitizing only about 1 times and 0.5 times on-balance-sheet assets, respectively.

The magnitude of securitizations relative to on-balance-sheet assets in Table 1 suggests that banks relying on securitization should seek to avoid the possibility of prolonged on-balancesheet funding. The firms and bank holding companies in Table 1 provided recourse to existing securitizations to avoid that fate.

Typical actions used to provide recourse in Table 1 are adding new, higher-quality accounts to a securitized pool (cherry picking) (Sears 9/11/91, Citicorp 3/15/93, Household 3/31/93, FCC 7/11/96, AT\&T 9/9/96, First Union 6/10/96); selling new receivables to the pool at a discount below par (Household 11/13/95, Mercantile 2/12/96, First Union 5/19/97, Prudential 5/96); increasing the credit enhancement (Sears 5/18/98, Banc One 3/5/97, Prudential 10/21/96, Tandy 8/93); getting investors to waive early amortization triggers (Sears 10/14/91, Citicorp 5/13/91); and getting the servicer (usually the sponsor) to reduce its fees (First Union 2/24/97). All violate the true sale provision of GAAP and RAP, yet none of the events resulted in 
regulatory or accounting restatements that added loans back onto bank balance sheets. The recourse events in Table 1 propped up 89 domestic and three foreign securities issues with a combined value of about $\$ 35.5$ billion, comprising almost $7.5 \%$ of the $\$ 475$ billion total public credit card asset-backed security domestic issuance reported on the Securities Data Corp. New Issues Database through May 2002.

Table 1 indicates that three recourse events occurred in each of 1991 and 1993. After only one event in 1995, six occurred in 1996 and another three in 1997. The last recourse event in our sample occurred in 1998. Looking at the distribution of events, it is not surprising that by 1996 regulators and accountants began to consider more strictly imposing the true sale provisions on securitization activity. At that time, the industry - if not regulators themselves - already recognized that recourse was a de facto, if not a de jure, violation of the true sale.

In September 1996 the Comptroller of the Currency issued its first official opinions on the treatment of implicit recourse, threatening to bring asset pools benefiting from implicit recourse back onto bank balance sheets. A March 31, 1997, article from Asset Sales Report put the issue most directly and succinctly. In that article, Lawrence W. Cohn, a senior vice president of equity research at PaineWebber, opined:

We have long been of the opinion that credit card securitizations are financing mechanisms rather than bona fide sales of assets... We certainly have no problem with banks using the securitization markets as a source of funding. But pretending that the assets have really been sold is another matter. Banks want sales treatment because they don't have to put up capital against securitized assets, and they don't have to post loss reserves either. But clearly the risks of ownership have not passed to buyers of securitized paper. In theory, every securitization is supposed to stand on its own. The issuer puts up sufficient excess receivables or in some other fashion enhances the pool as to garner investor confidence. In fact, if buyers and sellers miscalculate, the seller has always made up the difference rather than expose the buyers to risk. Thus, the putative seller in fact passes on none of the risks of ownership.

We don't know how long the fiction of sales treatment will last. ... the regulators are starting to think about these issues. ("Will Sales Treatment Survive a Recession?"). 
In late 1996, OCC Bulletin 1996-52: "Securitization-Guidelines for National Banks" maintained that "providing post-sale enhancements to prior asset sales constitutes recourse and would require full risk-based capital support for the entire pool of assets..." The Comptroller's Handbook in November 1997 reiterated those principles. Nonetheless, regulators seemed unwilling or unable to restrict implicit recourse, and the practices continued.

In 1999, the OCC again reiterated its concern in OCC Bulletin 1999-46: "Interagency Guidance on Asset Securitization Activities":

Recent examinations have disclosed significant weaknesses in the asset securitization practices of some insured depository institutions. These weaknesses raise concerns about the general level of understanding and controls among institutions that engage in such activities. The most frequently encountered problems stem from: (1) the failure to recognize and hold sufficient capital against explicit and implicit recourse obligations that frequently accompany securitizations... (p. 1).

OCC Guidance 2002-20, "Interagency Guidance on Implicit Recourse in Asset Securitizations," described explicit examples of what the agency considers implicit recourse, many of which are identical to the events in our sample:

Banking organizations typically have provided implicit recourse in situations where the originating organization perceived that the failure to provide this support, even though not contractually required, would damage its future access to the asset-backed securities market. An originating banking organization can provide implicit recourse in a variety of ways. The ultimate determination as to whether implicit recourse exists depends on the facts. However, as discussed in detail later in this document, the following actions point to a finding of implicit recourse:

- Selling assets to a securitization trust or other special purpose entity (SPE) at a discount from the price specified in the securitization documents, which is typically par value;

- Purchasing assets from a trust or other SPE at an amount greater than fair value;

- Exchanging performing assets for nonperforming assets in a trust or other SPE; and

- Funding credit enhancements beyond contractual requirements. By providing implicit recourse, a banking organization signals to the market that the risks inherent in the securitized assets are still held by the organization and, in effect, have not been transferred ...

Particular attention should be paid to revolving securitizations, such as those used for credit card lines ... where receivables generated by the lines are sold into the 
securitization. ...Once an early amortization event occurs, the banking organization could have difficulties using securitization as a continuing source of funding and, at the same time, have to fund the new receivables generated by the lines of credit on its balance sheet. Thus, banking organizations have an incentive to avoid early amortization by providing implicit support to the securitization. (pp. 3-4).

Regulatory rulings like these in the period from 1996 to the present prompted significant changes in the structure of more recent securitizations and in the type of recourse provided. Most recently, regulators have questioned the manner in which NextBank and First Consumers National Bank classified fraud losses in order to keep chargeoffs out of securitized pools, a more continuous form of implicit recourse. Hence, since 1998 the type of discrete actions of implicit recourse that are contained in our sample have not occurred, not because recourse is no longer an issue, but because the specific form of recourse we look at is now recognized and prohibited.

\section{Stock Price Effects of Recourse}

In this section we analyze the short- and long-term equity return effects associated with recourse on the recourse credit card bank sample (described previously) and a comparative benchmark non-recourse credit card bank sample.

\section{A. Short-term returns for the recourse credit card bank sample}

We analyze equity returns around 14 recourse events involving eight of the sponsors in Table $1{ }^{4}$ We calculate announcement period abnormal returns for firms in the recourse credit card bank sample using a standard market model, $\mathrm{R}_{\mathrm{i}, \mathrm{t}}=\alpha_{\mathrm{i}}+\beta_{\mathrm{i}} \mathrm{R}_{\mathrm{m}, \mathrm{t}}+\mathrm{e}_{\mathrm{i}, \mathrm{t}}$, where $\mathrm{R}_{\mathrm{i}, \mathrm{t}}$ is the return on day $t$ for the recourse announcing firm and $\mathrm{R}_{\mathrm{m}, \mathrm{t}}$ is the equally weighted CRSP index return on day $t$. The announcement day is defined as day 0 . The market model parameters, $\alpha_{i}$ and $\beta_{i}$, are estimated over the 200-day window ending 10 days prior to the announcement (day -210 to day

\footnotetext{
${ }^{4}$ Prudential was not publicly traded at the time of its recourse announcements, and we did not have an exact day for the Tandy recourse announcement. Hence, these events are excluded from the analysis.
} 
-10). Since our announcements generally come from newswire reports, it is possible that the news may have been released after the close of trading on the announcement day. Hence, we define the announcement period as the two-day window including the announcement day and the day following the announcement (day 0 to day 1). We use the cross-sectional test statistic of Boehmer, Musumeci, and Poulsen (1991) to test the significance of the abnormal returns. This statistic controls for event-induced variance increases associated with significant firm events. ${ }^{5}$

Table 2 contains the results of the event study conducted for the recourse credit card bank sample. As can be seen in Panel A, the two-day (day 0,1) abnormal return is positive and significant. It appears that the market reaction actually occurs on day 1, which has a positive, significant abnormal return of $1.36 \%$. This abnormal return is quite large and indicates that the market did not anticipate the recourse announcement.

Panel B contains the two-day abnormal returns for each of the individual events. Three observations about Panel B are important. First, 10 of the 14 events are associated with positive abnormal returns, suggesting that there are circumstances under which investors may view recourse in a negative light. ${ }^{6}$ The substantial variation in the magnitude of both positive and negative abnormal returns suggests the results in Panel A are not driven by a few large outliers. Second, there is not a discernible time trend to the abnormal returns. The four events associated with negative abnormal returns - Citibank 1992, Household Finance November 1995, Mercantile

\footnotetext{
${ }^{5}$ Higgins and Peterson (1998) show that the performance of the cross-sectional t-statistic of Boehmer, Musumeci, and Poulsen (1991) is superior relative to other test statistics.

${ }^{6}$ We also searched for asset-backed security return behavior around the events indicated. Out of twenty-seven trusts (sponsored by six banks) directly affected by recourse in Table 1, we found price data on seven trusts sponsored by three banks: First Union MCCT 1A, 1B, 2A, and 2B; Prudential Bank \& Trust MCCT II 1994-A; and Mercantile 1995 1A and 1B. First Union and Prudential experienced two recourse events during the period covered by the price data, allowing the analysis of twelve event/series pairs. Only two of these event/series pairs, Prudential MCCT II 1994-A in May 1996 and Mercantile 1995 1B in February 1996, showed changes to returns around the event dates. Both experienced increases in price following recourse, as would be expected. However, Prudential 1994 A did not show price effects in October 1996, nor did Mercantile 1995 1A in February 1996. Mercantile the sponsor did, however, experience negative stock price reactions in February 1996. While further analysis of price series would be interesting, data is severely lacking.
} 
Bank February 1996, and Sears Roebuck 1998 - do not appear clustered in any one time period, nor do abnormal returns appear changed following the OCC's September 1996 issuance limiting the ability of banks to provide support to failing credit-card-backed deals. Third, it appears that each recourse announcement conveys new information. In fact, many of the banks that have more than one recourse announcement actually have larger abnormal returns associated with subsequent announcements than those associated with the first recourse announcement.

\section{B. Short-term returns for the non-recourse credit card bank sample}

In the presence of asymmetric information, it is not uncommon for shareholders to infer information about the value of their company from information that comes from similar companies. ${ }^{7}$ This is indicative of the transfer of information that exists between firms in similar industries. We hypothesize that a similar phenomenon may exist for recourse credit card bank sample firms. Specifically, we hypothesize that the announcement of the provision of implicit recourse eliminates uncertainty about the industry's willingness to provide recourse and about the value that recourse has for securitizing firms. We therefore analyze whether there exists an information transfer between the recourse announcing firm and other firms that are securitizing credit card debt.

To test this hypothesis, we calculate abnormal returns associated with recourse announcements for a non-recourse credit card bank sample (other securitizing banks that did not provide recourse). For each year represented in the recourse sample, we identify all securitizing credit card sponsors listed in Faulkner \& Gray's Card Industry Directory that did not provide recourse at any time during the sample period. In the event that some of these banks did not report securitizations to Faulkner \& Gray, their issuance was confirmed using Lexis-Nexis

\footnotetext{
${ }^{7}$ For example, Szewczyk (1992) finds that the announcement of a seasoned equity offering by one company in an industry will create a negative price response for all companies in the industry.
} 
and the Securities Data Corp. New Issues Database and (far less detailed) call report data where available. Members of the non-recourse credit card bank sample for each year are identified Table $3 .^{8}$

To calculate abnormal returns for the non-recourse credit card bank sample, we use the portfolio approach suggested by Szewczyk (1992). For each recourse announcement, we create an equally weighted portfolio of returns for all firms in the non-recourse credit card bank sample over the period from -210 days prior to the announcement to 10 days after the announcement. Using the portfolio returns, market model parameters (described above) are estimated over the period from -210 days to - 10 days. Again, we define the announcement period as days 0 and 1 and use the cross-sectional t-statistic of Boehmer, Musumeci, and Poulsen (1991) to test for significance. Although we do not have returns data on Prudential (a non-public company) itself, we have an exact announcement date for one of the Prudential recourse announcements. Including that event in the analysis raises the number of events analyzed to 15.

Table 4 contains the results of the non-recourse credit card bank sample event study. Panel A contains average abnormal returns across all events. Significant positive abnormal returns for the non-recourse banks are found around the recourse announcement (days 0 and 1). The twoday announcement period abnormal return is $0.66 \%$ and is significant at the $1 \%$ level. Such a large abnormal return for the industry is rather surprising, suggesting that the market places a great deal of importance on the recourse announcements of other banks.

Panel B contains the results for the specific events investigated in the sample. Similar to the results found for the recourse sample, it is clear that the results are not driven by outliers. Ten

\footnotetext{
${ }^{8}$ The dollar amount of securitizations outstanding at the 92 banks ranges from more than $\$ 27$ billion for MBNA, representing $80 \%$ of MBNA's total (both on- and off-balance-sheet) credit card loans, to just under $\$ 39$ million at American General Financial Corp., representing about 7\% of American General's credit card loans. Average dollar amount of securitizations outstanding in the 92 banks is about $\$ 4$ billion, and median volume is about $\$ 987$ million. The average percent of total credit card loans securitized among these 92 banks is $53 \%$ and the median is $47 \%$.
} 
of the 15 events are associated with positive abnormal returns for the non-recourse banks. Only one of the events that generated large negative abnormal returns for the recourse sample (Household, 1995) is associated with negative abnormal returns for non-recourse banks. However, the magnitude of this and the other negative reactions among non-recourse credit card banks is small, averaging $-0.28 \%$, compared with the positive reactions, which average $1.13 \%$.

We observe that abnormal returns for the non-recourse credit card bank sample do not seem to be driven by outliers and do not illustrate a discernible time trend. Again, abnormal returns accompanying recourse remain positive after the 1996 OCC announcement of increased regulatory stringency. Thus, we conclude that recourse announcements convey significant positive information valuable to all credit card securitizing banks.

\section{Long-Run Stock Price and Operating Performance Effects of Recourse}

Section II suggests that the announcement of recourse by credit card banks has a substantial impact on both recourse credit card banks and non-recourse credit card banks. It is possible, however, that the market does not fully anticipate or properly value the information contained in important event announcements. In such cases, the effects associated with the announcement would be mitigated over time. Thus, the events may also have an impact on the long-run stock price and operating performance of the announcing firms. ${ }^{9} \mathrm{We}$ are interested in determining if such post-announcement effects exist for our recourse credit card bank sample firms.

We are also interested in determining why some banks provide recourse and others do not. An obvious reason for providing recourse is simple necessity. It may be that the banks in our sample are simply performing very poorly relative to other banks and must provide recourse as a

\footnotetext{
${ }^{9}$ For example, Loughran and Ritter (1995) find firms that announcing seasoned equity offerings experience stock price declines, relative to a matching sample of similar firms, for several years after the announcement and Loughran and Ritter (1997) find that the operating performance of firms announcing a seasoned equity offering also declines, relative to a matching sample, post-announcement.
} 
means to keep their issues afloat. Thus, in this section we examine long-run pre- and postannouncement stock price and operating performance of recourse credit card bank sample firms.

\section{A. Matching samples for long-term comparisons}

We use matching samples to determine if long-run performance among the recourse credit card bank sample firms is substantially different from that of other firms. Similar to other studies, our study creates matching samples by identifying matching firms comparable to each announcing firm. We identify matching firms using two methodologies. First, we match recourse credit card bank sample firms with others using a procedure similar to that of Loughran and Ritter (1997). According to this procedure, each firm in the recourse credit card bank sample is paired with another firm listed on the Compustat database based on SIC code, asset size, and book-to-market equity ratio. ${ }^{10}$ Potential matching firms have the same four-digit SIC code as the announcing firm and have an asset size between 25 percent and 200 percent of the announcing firm at the time of the recourse announcement. From these potential firms, we choose as matching firms those that have the closest book-to-market equity ratio to each recourse credit card bank sample firm. We call the resulting sample the size and book-to-market equity matched sample (SBEM sample).

The second matching sample is constructed by pairing each firm in the recourse credit card bank sample with its closest counterpart in the non-recourse credit card bank sample (described in section II.B) on the basis of outstanding securitization volume and portfolio size at the time of the recourse announcement. We call this the credit card issue size matched sample (CCISM sample).

\footnotetext{
${ }^{10}$ Barber and Lyon (1997) suggest including the book-to-market equity ratio as a matching variable.
} 
One problem that we encounter in examining long-run operating performance is the presence of multiple events occurring within a short period of time. Following the methodology of Loughran and Ritter (1997), we exclude subsequent recourse announcements occurring during the two years following a recourse announcement in the sample. ${ }^{11}$ Thus, the sample used for the examination of long-run performance contains 10 recourse-announcing firm observations. Table 5 lists the recourse credit card bank sample firms and the selected matching companies based on the two selection criteria.

\section{B. Long-term returns for the recourse credit card bank sample}

To examine the long-run stock price performance of recourse announcing banks, we compute buy and hold returns for one year before the recourse announcement and for two years after the recourse announcement. We calculate abnormal long-run returns for the recourse announcing firms using both the SBEM sample and CCISM sample as benchmark portfolios. The significance of the abnormal returns is tested using a nonparametric sign test.

Table 6 contains the results of the long-run median stock price performance tests (Appendix A contains individual firm results). Panel A shows the median buy and hold returns for the recourse credit card bank sample firms, the SBEM sample firms, and the CCISM sample firms. Panel B compares recourse credit card bank sample firms to the SBEM sample firms and the CCISM sample firms. One year prior to the announcement, returns for recourse credit card bank sample firms are significantly lower than those for CCISM sample firms. Two years postannouncement, returns for recourse credit card bank sample firms are significantly higher than those for SBEM sample firms. Thus, it appears that the recourse credit card bank sample firms are under-performing matching firms prior to the recourse announcement, perhaps leading to the

\footnotetext{
${ }^{11}$ Given data limitations due to mergers, we examine only stock price and operating performance in the two years after a recourse announcement; thus, we screen only for events occurring within two years.
} 
recourse announcement. After the recourse announcement, performance improves, suggesting that the provision of recourse does not result in a long-term cost to the recourse credit card bank sample firms in terms of stock price performance.

\section{Long-run operating performance}

In measuring long-run operating performance we examine five operating performance ratios: EBITDA to assets, profit margin, return on assets, EBITDA to sales, ${ }^{12}$ and return on equity. All operating performance data come from the Compustat database. We define year 0 as the fiscal year in which the recourse announcement occurs, and we examine operating performance over a two-year window before and after the recourse announcement (fiscal years 2 through +2 ). To determine if significant differences are present in the operating performance recourse credit card bank sample firms and the matching firms, the Wilcoxon signed-rank test is used. ${ }^{13}$ Additionally, we examine the change from fiscal year -2 to +1 and from +1 to +2 for the differences between the recourse credit card bank sample firm and matching firm ratios. Again, we use the Wilcoxon signed-rank test to determine if there are significant differences between recourse credit card bank sample firm ratios and the matching firm ratios.

Median operating performance results appear in Table 7 (Appendix B contains individual firm results). Panels A, B, and C contain summary median operating performance measures for the recourse credit card bank sample firms, the SBEM sample firms, and the CCISM sample firms. In general, it again appears that the operating performance of the recourse credit card bank sample firms deteriorates prior to the support announcement and improves after the support announcement.

\footnotetext{
${ }^{12}$ Sales is Compustat item 12, Sales-Net, the same item number used by Loughran and Ritter (1997). For banks, this item includes total current operating revenue and net pretax profit or loss on securities sold or redeemed.

${ }^{13}$ The method used to determine differences in operating performance follows that of Loughran and Ritter (1997).
} 
Those differences are confirmed statistically in Panels D, E, F, and G. Panel D examines annual differences in operating performance between recourse credit card bank sample firms and the SBEM matching firms and Panel E contains annual differences in operating performance between recourse credit card bank sample firms and the CCISM matching firms. In general, the annual differences between the recourse credit card bank sample firms and the matching firms are not statistically significant at conventional levels. When comparing recourse credit card bank sample firms to the SBEM sample the only statistically significant difference in operating performance occurs in the year following the announcement, where EBITDA to assets for recourse credit card bank sample firms are significantly lower than the SBEM firms. There are a few more statistically significant differences between recourse credit card bank sample firms and the CCISM sample. Profit margins for recourse announcing firms are substantially lower than the CCISM firms in the year of and the year after the recourse announcement. EBITDA to assets, however, is shown to be larger for recourse credit card bank sample firms two years after the recourse announcement. Thus, again, there appears to be some slight underperformance around the announcement and some indication of improvement after the announcement.

Examining performance changes over periods longer than one year yields more statistically significant differences. Panels F and G contain the median change from fiscal year -2 to +1 and from +1 to +2 in the ratios of recourse credit card bank sample firm performance measures relative to the SBEM and CCISM matched samples, respectively. Comparison of operating performance of recourse credit card bank sample firms to the SBEM firms shows that announcing firms have a statistically significant increase in operating performance after the recourse announcement, whether measured by EBITDA/assets, profit margin, return on assets, EBITDA/sales, or return on equity. Comparison of recourse credit card bank sample firms 
relative to the CCISM matched sample shows that the profit margin and EBITDA/sales for recourse credit card bank sample firms decreased by statistically significant amounts over the years prior to the announcement. Furthermore, EBITDA/assets, profit margin, return on assets, and return on equity for the recourse credit card bank sample firms increased by statistically significant amounts, relative to the CCISM sample, in the years following the announcement. These results are again similar to those found for long-run stock returns. Performance of the recourse credit card bank sample firms was poor prior to the announcement but improved postannouncement.

\section{Default Probability and Recourse}

Results for long-term equity returns and operating performance bring up the possibility that weak companies are the ones that provide recourse. If recourse credit card banks are weak enough, support may place the deposit insurance safety net at risk. We examine how weak our recourse credit card bank sample firms are by including well-known default prediction variables in a probit model of support to analyze their effect. The model is estimated on a data set constructed by combining the recourse credit card and non-recourse credit card bank samples. Finding that variables associated with default are similarly associated with support would suggest that ABS support is provided by firms at risk of default and/or insolvency.

We obtain our default prediction variables from the seven-variable ZETA ${ }^{\mathrm{TM}}$ model of Altman, Haldeman, and Narayanan (1977). Their well-known model accords well with basic finance theory, which suggests that the probability of insolvency should be an increasing function of asset risk and leverage. Additionally, asset liquidity (relative to liabilities) may also be a factor influencing the risk of failure. If the same relationships predict support, we surmise that support is provided by weak banks (those closer to default). 
The Altman, Haldeman, and Narayanan (1977) variables are return on assets; the variability of return on assets; the debt service ratio; accumulated profits; liquidity; the market to book ratio of capital; and size of the firm. We obtain data to compute the variables for our matched credit card bank sample from bank call reports, bank holding company Y-9 reports, and CRSP. Banks that provide recourse are coded as 1, and banks that do not provide recourse are coded as 0 .

Results of our Altman, Haldeman, and Narayanan (1977) variant appear in Table 8. Although Altman, Haldeman, and Narayanan (1977) associate lower return on assets, liquidity, capital, and size and higher standard deviations of return on assets and debt service ratios with default, we find the coefficients on return on assets, liquidity, capital, standard deviation of return on assets, and debt service ratios opposite those results (though the coefficients for capital and the debt service ratio are statistically insignificant). Only cumulative profitability and size obtain signs that suggest recourse may be associated with default, though only the coefficient on size is statically significant. This size coefficient may not be surprising, since we are using the union of the recourse and non-recourse credit card bank samples, and the firms providing recourse are typically not industry leaders. Hence, we find that firms providing recourse have higher return on assets, greater liquidity, less variability in return on assets, and are of smaller size than non-recourse credit card banks. On the basis of these results, it appears that providing recourse is not associated with the probability of default or insolvency in a manner that may place the safety net at risk. Rather, the strategy is used by firms that have liquidity sufficient to provide recourse and recover thereafter. 


\section{Subsequent Loan Sale Terms and Conditions}

Recourse is an indication that some aspect of the securitization was unanticipated, whether that be lower than expected credit quality, legal terms regarding the mechanics of disbursements, or regulatory action. Hence, while the bank or parent firm may not have suffered, subsequent deals may be structured in ways that help ensure investors avoid the default and reinvestment risks that accompany early amortization. Thus, we examine dimensions of pool size, support, and coupons for both A and B tranches, the underlying (tertiary) credit support, the average issue frequency prior to support, and the time between issues before and after the support event for our recourse credit card bank sample. For comparison we examine the same dimensions for the CCISM sample firms. This will allow us to determine if any observed changes in the recourse sample are firm specific or are associated with overall changes in the credit card securitization market.

\section{A. Changes in securitization terms for recourse credit card bank sample firms}

Table 9 lists attributes for recourse credit card bank sample deals brought to market before and after 10 of the support events listed in Table 1. The events relating to Mercantile, Prudential, and Tandy did not have any other comparison issues either before or after the recourse event. First Union's only issues were its 1996-1 and 1996-2, both of which required recourse. We hypothesize that, following recourse, ABS investors might expect increased enhancement for the pool to receive a desired rating, an increased coupon to compensate for higher unexpected risk, or higher levels of tertiary (C-class) credit enhancement for the entire deal.

Few of the comparisons in Table 9 illustrate evidence consistent with this hypothesis. Aclass and B-class enhancement rise in only one of the deal comparisons - that associated with the Sears Roebuck May 18, 1998, support event. In this case, the A-class enhancement level rose 
from $11.5 \%$ before support to over $15 \%$ after, and the B-class support rose from $7 \%$ to $9 \%$. Following the Household International November 13, 1995, support event the amount of enhancement rose, but the sponsor switched to a different type of enhancement, from a $12 \%$ collateral invested amount (CIA) to a $15.61 \%$ overcollateralization (OC). The other events exhibit the same or sometimes decreased support levels after the event.

Coupons are also typically the same or lower after the support event. The only increase evident in Table 9 is that for B-class coupons before and after the AT\&T Corp September 9, 1996, event.

All in all, it appears that few recourse events are associated with pool enhancement, tertiary enhancement, or coupon changes that could be associated with investor concern.

Market access, however, may pose an additional means by which investors react. The last two columns in Table 9 compare the average time between issues prior to recourse and the time between the before and after issues around the support event for our group of sponsors. Excepting the Sears Roebuck September 11, 1991, support event, which was followed closely by another support event for that sponsor, the time lapse between issues around the support event average over four times the interval between issues prior to the event. In two cases, Sears Roebuck May 18, 1998, and AT\&T Corp. September 9, 1996, sponsors took deals to market the day after support. In both cases, however, these sponsors waited a substantial period -411 days for Sears (308\% of the average issuance interval) and 317 days for AT\&T ( $310 \%$ of the average issuance interval) - before taking their next deals to market. Hence, although it appears sponsors eventually return to the market at terms similar to those prior to support, they often do not do so on the same schedule as prior to providing support. 


\section{B. Changes in securitization terms for CCISM sample firms}

Table 10 illustrates loan sale terms for 13 credit card issue size matching (CCISM) sample firms around each recourse credit card sample firm's related recourse announcement. Again, there is scant evidence of change in A- or B-tranche composition or pricing changes associated with recourse events.

Furthermore, average issuance intervals around recourse, on average, increase only about 2.3 times over the pre-recourse interval for the CCISM firms in Table 10 compared with over four times the pre-recourse interval for recourse credit card bank sample firms in Table 9. A lot of this increase is driven by one outlier, Chase, around Citigroup's March 1993 recourse announcement. In that case, Chase's issue interval increases over 10 times its pre-recourse interval. Excluding that outlier from the sample reduces the average increase for CCISM sample

firms to 1.46 times the pre-recourse interval. Hence, the time between issuance does not seem to increase around recourse events for CCISM sample firms as much as for recourse credit card bank sample firms. Thus, the increased time to issuance observed for the recourse bank sample does not appear to be associated with a marketwide effect, and it appears that, as with the commercial paper market, the penalty for recourse is market access.

\section{Summary and Conclusions}

This paper began by observing that securitization is believed to pose risks to sponsors of the underlying collateral. These risks are believed to be especially acute with revolving collateral, like credit card loans, because of the propensity for recourse provided by the sponsor. The paper documents 17 discrete recourse events that occurred during the 1990s and examines the effects of recourse to the sponsor by examining short- and long-term stock returns, long-term operating performance, default probabilities, and follow-on terms of securitization. 
The paper demonstrates that sponsor stock prices, on average, increase in both the shortand long-run following recourse. Long-run median operating performance also improves ex post. However, ex ante, the firms providing recourse are weaker than matched samples of their counterparts. Nonetheless, the firms providing recourse are not so weak as to suggest they face an imminent threat of default or insolvency, such that recourse could represent a significant threat to the bank safety net.

Despite improvements in stock returns and operating performance for the sponsor following recourse, it appears sponsors will face a penalty for unexpected performance shortfalls in their securitizations. Although terms of the securitizations (coupons, composition, credit enhancements) for the most part remain consistent when firms return to market after recourse, the paper documents that firms providing recourse may face long delays before returning to market. Hence, much like with commercial paper, although there appears to be little time series variation in the contractual terms of securitizations, firms face market exclusion if they demonstrate an inability to sell sound investment-grade paper.

The results outlined above should not be construed as favoring recourse. While positive results following recourse suggest that sponsors act rationally, recourse still violates FASB 140 and regulatory restrictions governing the true sale of assets. Furthermore, recourse represents an implicit contractual provision that is not disclosed to the sponsor's investors. However, the results presented in this paper suggest that recourse can be valuable and can benefit the sponsor and that there may be a gray area between treating assets as "sold" and taking them off balance sheets and treating them as "retained" and keeping them on. Clarifying this distinction and measuring, analyzing, and parameterizing that gray area are therefore important topics for future research. 


\section{References}

$A B C$ 's of Credit Card ABS. New York: Fitch Investors Service, 1997.

Altman, Edward I., Haldeman, Robert G., and Narayanan, P. "ZETA'M Analysis: A New Model to Identify Bankruptcy Risk of Corporations." Journal of Banking and Finance 1-1 (January 1977): 29-54.

Barber, Brad and Lyon, J. "Detecting Long-Run Abnormal Stock Returns: The Empirical Power and Specification of Test Statistics," Journal of Financial Economics 43 (March 1997): 341-372.

Boehmer, Ekkehart, Musumeci, Jim, and Poulsen, Annette B. "Event Study Methodology Under Conditions of Event-Induced Variance.” Journal of Financial Economics 30-2 (December 1991): 253-272.

Calomiris, Charles W., and Mason, Joseph R. "Credit Card Securitization and Regulatory Arbitrage" Mimeo: Drexel University, 2003.

Card Industry Directory. New York: Faulkner \& Gray, various years.

Higgins, Eric J and Peterson, David. "The Power of One and Two Sample t-Statistics Given Event-Induced Variance Increases and Non-Normal Stock Returns: A Comparative Study," Quarterly Journal of Business and Economics 37-1 (Winter1998): 27-49.

Jones, David. "Emerging Problems with the Basel Capital Accord: Regulatory Capital Arbitrage and Related Issues." Journal of Banking and Finance 24-1-2 (January 2000): 35-58.

Loughran, Tim, and Ritter, Jay R. “The New Issues Puzzle," Journal of Finance 50 (March 1995): 23-51.

Loughran, Tim, and Ritter, Jay.R. "The Operating Performance of Firms Conducting Seasoned Equity Offerings.” Journal of Finance 52-5 (December 1997): 1823-1850.

Moody's. "The Costs and Benefits of Supporting 'Troubled' Asset-Backed Securities: Has the Balance Shifted?” (January 1997).

OCC Guidance 2002-20. Interagency Guidance on Implicit Recourse in Asset Securitizations.

Szewczyk, Samuel H. “The Intra-Industry Transfer of Information Inferred from Announcements of Corporate Security Offerings.” Journal of Finance 47-5 (December 1992): 1935-1945.

“Will Sales Treatment Survive a Recession?” Asset Sales Report, 11-13 (March 31, 1997): 1. 
Table 1

Sample Description

\begin{tabular}{|c|c|c|c|c|c|c|}
\hline Company & $\begin{array}{l}\text { Managed Credit } \\
\text { Card Loans as } \\
\text { Percent of } \\
\text { Consolidated Firm } \\
\text { (BHC) On-balance } \\
\text { Sheet Total Assets }\end{array}$ & $\begin{array}{c}\text { Bank's On- } \\
\text { balance Sheet } \\
\text { Credit Card Loans } \\
\text { as Percent of } \\
\text { Consolidated Firm } \\
\text { (BHC) On-balance } \\
\text { Sheet Credit Card } \\
\text { Loans }\end{array}$ & $\begin{array}{c}\text { Managed Credit } \\
\text { Card Loans as } \\
\text { Percent of Bank's } \\
\text { On-balance Sheet } \\
\text { Total Assets }\end{array}$ & $\begin{array}{l}\text { Announcement } \\
\text { Date }\end{array}$ & Trusts Supported & Support Provided \\
\hline Sears Roebuck and Company & $54 \%$ & $100 \%$ & $1,682 \%$ & 9/11/91 & Sears Credit Account Trust 1990-C & Added higher quality accounts \\
\hline Sears Roebuck and Company & $54 \%$ & $100 \%$ & $1,682 \%$ & $10 / 14 / 91$ & $\begin{array}{l}\text { Sears Credit Account Trust 1990-A,D,E and } \\
\text { 1989-C,E }\end{array}$ & Removed early amortization trigger \\
\hline Sears Roebuck and Company & $54 \%$ & $100 \%$ & $1,682 \%$ & $5 / 18 / 98$ & Sears Credit Account Master Trust II & $\begin{array}{l}\text { Increased credit enhancement - } \\
\text { Ratings affirmation followed }\end{array}$ \\
\hline Citibank & $17 \%$ & $\begin{array}{c}72 \% \\
(\mathrm{NV}, \mathrm{SD})\end{array}$ & $184 \%$ & $5 / 13 / 91$ & $\begin{array}{l}\text { Standard Credit Card Trust } 1989-2,3,4,5 \text { and } \\
1990-1\end{array}$ & Lowered base rate by $2.3 \%$ \\
\hline Citibank & $17 \%$ & $\begin{array}{c}72 \% \\
(\mathrm{NV}, \mathrm{SD})\end{array}$ & $184 \%$ & $3 / 15 / 93$ & $\begin{array}{l}\text { National Credit Card Trust 1989-2,4,5 } \\
\text { Standard Credit Card Trust 1990-1,3,4 } \\
\text { European Credit Card Trust 1989-1,2 and 1990-1 }\end{array}$ & $\begin{array}{l}\text { Added new accounts- } \\
\text { Ratings affirmation followed }\end{array}$ \\
\hline Household Finance & $61 \%$ & $100 \%$ & $186 \%$ & $3 / 31 / 93$ & Household Credit Trust 1991-2 & $\begin{array}{l}\text { Added new accounts - } \\
\text { Ratings affirmation followed }\end{array}$ \\
\hline Household Finance & $61 \%$ & $100 \%$ & $186 \%$ & $11 / 13 / 95$ & $\begin{array}{l}\text { Household Private Label Master Credit Card } \\
\text { Trust II }\end{array}$ & $\begin{array}{l}\text { Added new accounts, increased } \\
\text { discount on receivables - } \\
\text { Ratings affirmation followed }\end{array}$ \\
\hline Mercantile Bank & $7 \%$ & $\begin{array}{c}51 \% \\
\text { (Hartford, IL) }\end{array}$ & $309 \%$ & $2 / 12 / 96$ & Mercantile Credit Card Master Trust 1995-1 & $\begin{array}{l}\text { Added discounted receivables - } \\
\text { Ratings affirmation followed }\end{array}$ \\
\hline FCC National Bank & $17 \%$ & $\begin{array}{l}95 \% \\
\text { (DE) }\end{array}$ & $188 \%$ & $7 / 11 / 96$ & First Chicago Master Trust II & $\begin{array}{l}\text { Added new accounts - } \\
\text { Ratings affirmation followed }\end{array}$ \\
\hline AT\&T & $24 \%$ & $100 \%$ & $26,531 \%$ & 9/9/96 & AT\&T Universal Card Master Trust & Added new accounts \\
\hline Banc One Corporation & $10 \%$ & $\begin{array}{c}25 \% \\
\text { (Dayton, OH) }\end{array}$ & $205 \%$ & $3 / 5 / 97$ & Banc One Master Credit Card Trust & $\begin{array}{l}\text { Increased credit enhancement - } \\
\text { Ratings affirmation followed }\end{array}$ \\
\hline First Union & $5 \%$ & $99 \%(\mathrm{GA})$ & $52 \%$ & $6 / 10 / 96$ & First Union Master Credit Card Trust & Removed lower quality accounts \\
\hline First Union & $5 \%$ & $99 \%(\mathrm{GA})$ & $52 \%$ & $2 / 24 / 97$ & First Union Master Credit Card Trust 1996-1 & Waived servicing fee \\
\hline First Union & $5 \%$ & $99 \%(\mathrm{GA})$ & $52 \%$ & $5 / 19 / 97$ & First Union Master Credit Card Trust 1996-1,2 & Added discounted receivables \\
\hline Prudential Bank and Trust & $\mathrm{NA}^{\mathrm{a}}$ & $100 \%$ & $101 \%$ & $10 / 21 / 96$ & PB\&T Master Credit Card Trust II 1994-A & $\begin{array}{l}\text { Increased credit enhancement - } \\
\text { Ratings affirmation followed }\end{array}$ \\
\hline Prudential Bank and Trust & $\mathrm{NA}^{\mathrm{a}}$ & $100 \%$ & $101 \%$ & $5 / 96$ & PB\&T Master Credit Card Trust II 1994-A & Added discounted receivables \\
\hline Tandy Corporation & $32 \%$ & $100 \%$ & $3,919 \%$ & $8 / 93$ & Tandy Master Trust Series A & Increased credit enhancement \\
\hline
\end{tabular}

${ }^{a}$ Prudential Bank and Trust is owned by a non-public insurance company. 


\section{Table 2}

\section{Abnormal Stock Returns for Credit Card Banks Announcing Recourse}

The following table contains abnormal stock returns for credit card banks that announce the provision of recourse to an outstanding credit card securitization for the 10 days prior to and the 10 days following the recourse announcement date. We examine a two-day announcement widow, the announcement day (Day 0) and the following day (Day 1), to determine the market's reaction to the announcement. The significance of the abnormal returns is tested using the cross-sectional test statistic of Boehmer, Musumeci, and Poulsen (1991). The sample size is 14. Panel A contains average abnormal returns across all events. Panel B contains the two-day announcement window return and the standardized abnormal return for the individual events. * indicates significance at the 0.10 level, ${ }^{* *}$ indicates significance at the 0.05 level, and $* * *$ indicates significance at the 0.01 level

Panel A: Average Abnormal Returns

\begin{tabular}{cccc} 
Days & Average abnormal return & $\begin{array}{c}\text { Standard deviation of } \\
\text { abnormal returns }\end{array}$ & Cross-sectional t-statistic \\
\hline-10 & 0.0008 & 0.0110 & 0.1812 \\
-9 & $-0.0055^{* *}$ & 0.0115 & -2.2634 \\
-8 & -0.0079 & 0.0216 & -1.3130 \\
-7 & 0.0003 & 0.0105 & 0.3164 \\
-6 & -0.0018 & 0.0171 & -0.4189 \\
-5 & $0.0057^{*}$ & 0.0112 & 1.9777 \\
-4 & 0.0051 & 0.0227 & 0.8204 \\
-3 & 0.0008 & 0.0163 & 0.1233 \\
-2 & 0.0029 & 0.0127 & 0.8358 \\
-1 & -0.0004 & 0.0173 & -0.4732 \\
0 & -0.0037 & 0.0103 & -1.4719 \\
1 & $0.0136^{* * *}$ & 0.0126 & 3.8380 \\
2 & 0.0027 & 0.0210 & 0.0391 \\
3 & 0.0000 & 0.0116 & 0.0276 \\
4 & $-0.0066^{* * *}$ & 0.0106 & -2.6182 \\
5 & 0.0049 & 0.0132 & 1.2834 \\
6 & -0.0036 & 0.0114 & -1.1707 \\
7 & 0.0008 & 0.0145 & -0.1222 \\
8 & $0.0062^{*}$ & 0.0116 & 1.9437 \\
9 & 0.0028 & 0.0167 & 0.3241 \\
10 & 0.0067 & 0.0155 & 1.7185 \\
0,1 & $0.0100^{* *}$ & 0.0163 & 2.1927 \\
\hline
\end{tabular}


Table 2...Continued

Abnormal Stock Returns for Credit Card Banks Announcing Recourse

Panel B: Two-Day Announcement Window Abnormal Returns for All Events

\begin{tabular}{|c|c|c|c|}
\hline Announcing Firm & Announcement Date & $\begin{array}{c}\text { Two-Day (Days 0,1) } \\
\text { Abnormal Return }\end{array}$ & $\begin{array}{c}\text { Standardized Two-Day } \\
\text { Abnormal Return }\end{array}$ \\
\hline Citibank & $5 / 13 / 91$ & -0.0047 & -0.1182 \\
\hline Sears Roebuck and Co. & $9 / 11 / 91$ & 0.0055 & 0.2322 \\
\hline Sears Roebuck and Co. & $10 / 14 / 91$ & 0.0292 & 1.2677 \\
\hline Citibank & $3 / 15 / 93$ & 0.0333 & 1.3199 \\
\hline Household Finance & $3 / 31 / 93$ & 0.0026 & 0.1102 \\
\hline Household Finance & $11 / 13 / 95$ & -0.0123 & -0.5120 \\
\hline Mercantile Bank & $2 / 12 / 96$ & -0.0126 & -0.9251 \\
\hline First Union & $6 / 10 / 96$ & 0.0030 & 0.1587 \\
\hline FCC National Bank & $7 / 11 / 96$ & 0.0234 & 1.0278 \\
\hline AT\&T & 9/9/96 & 0.0221 & 0.8687 \\
\hline First Union & $2 / 24 / 97$ & 0.0079 & 0.4059 \\
\hline Banc One Corp. & $3 / 5 / 97$ & 0.0313 & 1.4116 \\
\hline First Union & $5 / 19 / 97$ & 0.0191 & 1.1048 \\
\hline \multirow{4}{*}{ Sears Roebuck and Co. } & $5 / 18 / 98$ & -0.0081 & -0.2574 \\
\hline & Mean & 0.0010 & 0.4353 \\
\hline & Median & 0.0067 & 0.3190 \\
\hline & Standard Deviation & 0.0163 & 0.7429 \\
\hline
\end{tabular}


Table 3

Non-Recourse Credit Card Bank Sample Composition

\begin{tabular}{lcccccc}
\hline \multicolumn{1}{c}{ Name } & 1991 & 1993 & 1995 & 1996 & 1997 & 1998 \\
\hline Advanta NB, USA & X & X & X & X & X & \\
American Express Centurion Bank & & & & X & X & X \\
American General Financial Center & & & X & X & X & \\
Bank of America, NA & & X & & X & X & X \\
Bank of New York, DE & X & X & X & X & & \\
Capital One Bank & & & X & X & X & X \\
Carolina First Bank & & & X & X & X & X \\
Chase Manhattan Bank USA, NA & X & X & X & X & X & X \\
Chemical Bank & X & X & & & & \\
First Commerce Bancshares & & & & X & X & \\
First USA Bank & & X & X & X & X & \\
Firstar & & & & & & X \\
Fleet National Bank & & & & & & X \\
MBNA America, NA & X & X & X & X & X & X \\
Mellon Bank Corp. & & & X & X & X & X \\
National City Bank & X & X & X & X & X & X \\
NationsBank, NA & X & X & X & X & X & X \\
Norwest Bank IA, NA & X & X & X & & & \\
Peoples Bank & & X & X & X & X & X \\
Providian National Bank & & & X & X & X & \\
Signet Bank & X & X & X & X & X & \\
Valley National Bank & X & & & & & \\
Wachovia Bank, NA & & & & X & X & X \\
Wells Fargo Bank & & & & X & & X \\
Zions First NB & & X & X & X & X & X \\
\hline
\end{tabular}




\section{Table 4}

\section{Abnormal Stock Returns for Non-Recourse Providing Credit Card ABS Sponsors Associated with an Announcement of Recourse}

The following table contains abnormal stock returns for all non-recourse providing banks issuing credit card backed debt for the 10 days prior to and the 10 days following the announcement of the provision of recourse for a credit card securitization. Also, the cumulative abnormal return over the announcement day (Day 0) and the following day (Day 1) is included. Abnormal returns are calculated for the portfolio of all firms identified as credit card backed debt sponsors at the time of a support announcement. The significance of the abnormal returns is tested using the cross-sectional test statistic of Boehmer, Musumeci, and Poulsen (1991). Panel A contains average abnormal returns across the whole sample. Panel B contains two-day abnormal returns and standardized abnormal returns for the individual events. The sample size is $15 . *$ indicates significance at the 0.10 level, $* *$ indicates significance at the 0.05 level, and $* * *$ indicates significance at the 0.01 level

Panel A: Average Abnormal Returns

\begin{tabular}{|c|c|c|c|}
\hline Days & Average abnormal return & $\begin{array}{c}\text { Standard deviation of } \\
\text { abnormal returns }\end{array}$ & Cross-sectional t-statistic \\
\hline-10 & 0.0013 & 0.0078 & 0.6964 \\
\hline-9 & -0.0019 & 0.0083 & -0.9733 \\
\hline-8 & -0.0037 & 0.0115 & -1.3194 \\
\hline-7 & -0.0035 & 0.0068 & -1.6652 \\
\hline-6 & 0.0006 & 0.0093 & 0.6366 \\
\hline-5 & -0.0006 & 0.0079 & -0.7110 \\
\hline-4 & 0.0017 & 0.0087 & 0.4823 \\
\hline-3 & 0.0002 & 0.0060 & 0.2001 \\
\hline-2 & 0.0023 & 0.0096 & 0.8755 \\
\hline-1 & 0.0007 & 0.0059 & 0.4672 \\
\hline 0 & $0.0039 * *$ & 0.0078 & 2.0404 \\
\hline 1 & $0.0027 * *$ & 0.0058 & 2.1622 \\
\hline 2 & -0.0010 & 0.0106 & -0.1048 \\
\hline 3 & 0.0013 & 0.0080 & 0.6650 \\
\hline 4 & -0.0027 & 0.0068 & -1.4459 \\
\hline 5 & 0.0001 & 0.0074 & -0.0633 \\
\hline 6 & 0.0006 & 0.0104 & 0.0245 \\
\hline 7 & 0.0018 & 0.0098 & 0.8302 \\
\hline 8 & 0.0027 & 0.0070 & 1.3787 \\
\hline 9 & -0.0009 & 0.0087 & -0.4194 \\
\hline 10 & 0.0023 & 0.0075 & 1.1954 \\
\hline 0,1 & $0.0066 * * *$ & 0.0093 & 2.9800 \\
\hline
\end{tabular}


Table 4...Continued

\section{Abnormal Stock Returns for Non-Recourse Providing Credit Card ABS Sponsors Associated with an Announcement of Recourse}

Panel B: Two-Day Announcement Window Abnormal Returns for Non-Recourse Providing Credit Card Banks

\begin{tabular}{lccc}
\hline \multicolumn{1}{c}{ Announcing Firm } & Announcement Date & $\begin{array}{c}\text { Two-Day (Days 0,1) } \\
\text { Abnormal Return for } \\
\text { Non-Recourse Providing } \\
\text { Credit Card Banks }\end{array}$ & $\begin{array}{c}\text { Standardized Two-Day } \\
\text { Abnormal Return for } \\
\text { Non-Recourse Providing } \\
\text { Credit Card Banks }\end{array}$ \\
\hline Citibank & $5 / 13 / 91$ & 0.0027 & 0.1027 \\
Sears Roebuck and Co. & $9 / 11 / 91$ & -0.0063 & -0.2845 \\
Sears Roebuck and Co. & $10 / 14 / 91$ & 0.0266 & 1.4457 \\
Citibank & $3 / 15 / 93$ & -0.0005 & -0.0388 \\
Household Finance & $3 / 31 / 93$ & -0.0041 & -0.3218 \\
Household Finance & $11 / 13 / 95$ & -0.0026 & -0.2668 \\
Mercantile Bank & $2 / 12 / 96$ & 0.0063 & 0.6010 \\
First Union & $6 / 10 / 96$ & -0.0004 & -0.0346 \\
FCC National Bank & $7 / 11 / 96$ & 0.0199 & 1.8446 \\
AT\&T & $9 / 9 / 96$ & 0.0152 & 1.4498 \\
Prudential Bank and Trust & $10 / 21 / 96$ & 0.0015 & 0.1386 \\
First Union & $2 / 24 / 97$ & 0.0101 & 0.9410 \\
Banc One Corp. & $3 / 5 / 97$ & 0.0114 & 1.0596 \\
First Union & $5 / 19 / 97$ & 0.0109 & 0.8630 \\
Sears Roebuck and Co. & $5 / 18 / 98$ & 0.0087 & 0.6577 \\
\cline { 2 - 4 } & & Mean & 0.5438 \\
& & 0.0066 & 0.6010 \\
& Standard Deviation & 0.0063 & 0.7068 \\
\hline
\end{tabular}


Table 5

Matched Sample Composition

\begin{tabular}{lrll}
\hline & & \multicolumn{1}{c}{$\begin{array}{c}\text { Industry, Size, and } \\
\text { Book-to-Market } \\
\text { Matched Sample } \\
\text { Recourse Provider }\end{array}$} & $\begin{array}{c}\text { Credit Card Bank } \\
\text { Issue Size Matched } \\
\text { Sample }\end{array}$ \\
\hline Citigroup & $5 / 13 / 1991$ & Bank of America & Chase \\
Sears & $9 / 11 / 1991$ & Wal Mart & Bank of New York \\
Household Int'1 & $3 / 31 / 1993$ & Beneficial & Advanta \\
Tandy & $8 / 1 / 1993$ & Circuit City & Charming Shoppes \\
Mercantile & $2 / 12 / 1996$ & Compass & National City Corp \\
First Union & $6 / 10 / 1996$ & KeyCorp & Peoples Bank \\
First Chicago & $7 / 11 / 1996$ & BankBoston & Chase \\
AT\&T & $9 / 9 / 1996$ & Verizon & Capital One \\
Bank One & $3 / 5 / 1997$ & FleetBoston & Bank of America \\
Sears & $5 / 18 / 1998$ & JC Penny & MBNA \\
\hline
\end{tabular}




\section{Table 6 \\ Holding Period Returns for Recourse Announcing and Matching Firms}

The following table contains holding period returns for recourse announcing firms and for two different matching samples. Returns are calculated for one-year pre-announcement, one-year post-announcement, and two-year post announcement holding periods. Panel A contains median long-run returns for the recourse firms, and for firms in the two matching samples. Panel B contains the median difference in returns for recourse announcing firms relative to a sample of firms matched on size and book-to-market equity. The matching procedure used is similar to that of Loughran and Ritter (1997). Panel C contains the median difference in returns for recourse announcing firms relative to a sample of firms matched on the amount of outstanding credit-card backed issuances at the time of the support announcement. Sign tests are conducted to determine if significant differences in the returns of the announcing and matching firms exists. * indicates a significant difference at the $10 \%$ level, $* *$ indicates a significant difference at the $5 \%$ level, and $* * *$ indicates a significant difference at the $1 \%$ level for the sign test

Panel A: Median holding period returns for recourse announcing firms, size and book-to-market equity matched firms, and credit card issue size matched firms

\begin{tabular}{lccc}
\hline & \multicolumn{3}{c}{ Holding Period } \\
\cline { 2 - 4 } & $\begin{array}{c}\text { One Year Pre- } \\
\text { Announcement }\end{array}$ & $\begin{array}{c}\text { One Year Post- } \\
\text { Announcement }\end{array}$ & $\begin{array}{c}\text { Two Years Post- } \\
\text { Announcement }\end{array}$ \\
\cline { 2 - 4 } Recourse announcing firms & 0.2088 & 0.2918 & 0.9001 \\
$\begin{array}{l}\text { Size and book-to-market equity } \\
\text { matched firms (SBEM Sample) }\end{array}$ & 0.3667 & 0.3298 & 0.4065 \\
$\begin{array}{l}\text { Credit card issue size matched firms } \\
\text { (CCISM Sample) }\end{array}$ & 0.3988 & 0.4646 & 0.7870 \\
\hline
\end{tabular}

Panel B: Median difference in holding period returns for announcing firms and matched firms

Announcing Returns Minus SBEM

Matching Firm Returns

Announcing Returns Minus CCISM

Matching Firm Returns
Holding Period

\begin{tabular}{ccc} 
& Holding Period & \\
\hline $\begin{array}{c}\text { One Year Pre- } \\
\text { Announcement }\end{array}$ & $\begin{array}{c}\text { One Year Post- } \\
\text { Announcement }\end{array}$ & $\begin{array}{c}\text { Two Years Post- } \\
\text { Announcement }\end{array}$ \\
\hline-0.1314 & 0.0112 & $0.1659^{*}$ \\
$-0.0931^{*}$ & -0.2266 & 0.0026
\end{tabular}




\section{Table 7 \\ Median Operating Performance Measures for Recourse Announcing Firms and Differences in Medians between Announcing and Matching Firms}

Panels A, B, and C contain median operating performance measures for recourse announcing firms, size and bookto-market equity matched firms, and issue size matched firms. Panel D contains the difference in median operating performance between announcing firms and a size and book-to-market equity matched sample of firms. The matching procedure is similar to that used by Loughran and Ritter (1997). Panel E contains the difference in median operating performance between the announcing firms and a matched sample of firms chosen based on the amount of credit-card backed securities outstanding in the year of the support announcement. Panels F and G contain the change from fiscal year -2 to +1 and from +1 to +2 in the announcing firm ratios relative to the size and book-tomarket equity matched firms and the issue size matched firms, respectively. Z-statistics are calculated using the Wilcoxon signed-rank test to determine the equality of the distributions between the announcing firms and the matching firms. * indicates a significant difference at the $10 \%$ level, ** indicates a significant difference at the $5 \%$ level, and $* * *$ indicates a significant difference at the $1 \%$ level. There are 10 announcing firm observations available in years -2 through +1 and 9 available in year +2 .

Panel A: Recourse credit card bank sample firms median operating performance measures

\begin{tabular}{cccccc}
$\begin{array}{c}\text { Fiscal year } \\
\text { relative to } \\
\text { support year }\end{array}$ & EBITDA/Assets & $\begin{array}{c}\text { Profit } \\
\text { margin }\end{array}$ & $\begin{array}{c}\text { Return on } \\
\text { assets }\end{array}$ & $\begin{array}{c}\text { EBITDA/ } \\
\text { Sales }^{\mathrm{a}}\end{array}$ & $\begin{array}{c}\text { Return on } \\
\text { Equity }\end{array}$ \\
\hline-2 & 0.0456 & 0.0524 & 0.0136 & 0.2612 & 0.1558 \\
-1 & 0.0395 & 0.0422 & 0.0101 & 0.2340 & 0.1341 \\
0 & 0.0424 & 0.0829 & 0.0116 & 0.2745 & 0.1356 \\
1 & 0.0351 & 0.0853 & 0.0120 & 0.2589 & 0.1599 \\
2 & 0.0398 & 0.0881 & 0.0155 & 0.2809 & 0.1757 \\
\hline
\end{tabular}

Panel B: Size and book-to-market equity matched (SBEM) sample median operating performance measures

\begin{tabular}{cccccc}
$\begin{array}{c}\text { Fiscal year } \\
\text { relative to } \\
\text { support year }\end{array}$ & EBITDA/Assets & $\begin{array}{c}\text { Profit } \\
\text { margin }\end{array}$ & $\begin{array}{c}\text { Return on } \\
\text { assets }\end{array}$ & $\begin{array}{c}\text { EBITDA/ } \\
\text { Sales }^{\mathrm{a}}\end{array}$ & $\begin{array}{c}\text { Return on } \\
\text { Equity }\end{array}$ \\
\hline-2 & 0.0660 & 0.0798 & 0.0110 & 0.3144 & 0.1587 \\
-1 & 0.0597 & 0.0959 & 0.0129 & 0.2878 & 0.1707 \\
0 & 0.0582 & 0.0989 & 0.0147 & 0.3166 & 0.1637 \\
1 & 0.0572 & 0.0904 & 0.0137 & 0.3283 & 0.1766 \\
2 & 0.0733 & 0.0939 & 0.0124 & 0.3324 & 0.1549 \\
\hline
\end{tabular}

Panel C: Credit card issue size matched (CCISM) sample median operating performance measures

\begin{tabular}{cccccc}
\hline $\begin{array}{c}\text { Fiscal year } \\
\text { relative to } \\
\text { support year }\end{array}$ & EBITDA/Assets & $\begin{array}{c}\text { Profit } \\
\text { margin }\end{array}$ & $\begin{array}{c}\text { Return on } \\
\text { assets }\end{array}$ & $\begin{array}{c}\text { EBITDA/ } \\
\text { Sales }^{\mathrm{a}}\end{array}$ & $\begin{array}{c}\text { Return on } \\
\text { Equity }\end{array}$ \\
\hline-2 & 0.0321 & 0.1136 & 0.0121 & 0.2860 & 0.1670 \\
-1 & 0.0329 & 0.1210 & 0.0128 & 0.2978 & 0.1667 \\
0 & 0.0324 & 0.1228 & 0.0131 & 0.3163 & 0.1554 \\
1 & 0.0338 & 0.1126 & 0.0130 & 0.3279 & 0.1691 \\
2 & 0.0342 & 0.1327 & 0.0125 & 0.3559 & 0.1535 \\
\hline
\end{tabular}

(continued) 
Table 7...continued

Median Operating Performance Measures for Recourse Announcing Firms and Differences in Medians between Announcing and Matching Firms

Panel D: Differences between recourse credit card bank sample firms and size and book-to-market equity | matched (SBEM) firms

\begin{tabular}{cccccc}
\hline $\begin{array}{c}\text { Fiscal year } \\
\text { relative to } \\
\text { support year }\end{array}$ & EBITDA/Assets & $\begin{array}{c}\text { Profit } \\
\text { margin }\end{array}$ & $\begin{array}{c}\text { Return on } \\
\text { assets }\end{array}$ & $\begin{array}{c}\text { EBITDA/ } \\
\text { Sales }^{\mathrm{a}}\end{array}$ & $\begin{array}{c}\text { Return on } \\
\text { Equity }\end{array}$ \\
\hline-2 & -0.0004 & 0.0012 & 0.0001 & 0.0075 & -0.0095 \\
-1 & -0.0027 & 0.0022 & -0.0018 & 0.0091 & -0.0148 \\
0 & -0.0008 & -0.0155 & -0.0024 & -0.0022 & -0.0269 \\
1 & $-0.0028^{*}$ & -0.0054 & -0.0022 & -0.0184 & -0.0215 \\
2 & 0.0010 & 0.0107 & 0.0001 & 0.0057 & 0.0231 \\
\hline
\end{tabular}

Panel E: Differences between recourse credit card bank sample firms and credit card issue size matched (CCISM) firms

\begin{tabular}{cccccc}
$\begin{array}{c}\text { Fiscal year } \\
\text { relative to } \\
\text { support year }\end{array}$ & EBITDA/Assets & $\begin{array}{c}\text { Profit } \\
\text { margin }\end{array}$ & $\begin{array}{c}\text { Return on } \\
\text { assets }\end{array}$ & $\begin{array}{c}\text { EBITDA/ } \\
\text { Sales }^{\mathrm{a}}\end{array}$ & $\begin{array}{c}\text { Return on } \\
\text { Equity }\end{array}$ \\
\hline-2 & $0.0205^{*}$ & 0.0082 & 0.0022 & 0.0413 & -0.0043 \\
-1 & 0.0073 & -0.0117 & 0.0006 & 0.0049 & -0.0282 \\
0 & 0.0112 & $-0.0369^{* *}$ & -0.0012 & -0.0112 & -0.0329 \\
1 & 0.0065 & $-0.0268^{* *}$ & -0.0013 & -0.0219 & -0.0202 \\
2 & $0.0159^{* *}$ & -0.0159 & 0.0025 & -0.0101 & 0.0340 \\
\hline
\end{tabular}

Panel F: Median change in the ratios of recourse credit card bank sample firms performance measures relative to the size and book-to-market equity matched (SBEM) sample

\begin{tabular}{cccccc} 
Time Period & EBITDA/Assets & $\begin{array}{c}\text { Profit } \\
\text { margin }\end{array}$ & $\begin{array}{c}\text { Return on } \\
\text { assets }\end{array}$ & $\begin{array}{c}\text { EBITDA/ } \\
\text { Sales }^{\mathrm{a}}\end{array}$ & $\begin{array}{c}\text { Return on } \\
\text { Equity }\end{array}$ \\
\hline-2 to +1 & 0.0002 & -0.0326 & -0.0039 & -0.0254 & -0.0324 \\
+1 to +2 & $0.0093^{* * *}$ & $0.0212^{* *}$ & $0.0061^{* * *}$ & $0.0255^{* *}$ & $0.0312^{* * *}$ \\
\hline
\end{tabular}

Panel G: Median change in the ratios of recourse credit card bank sample firms performance measures relative to the credit card issue size matched (CCISM) sample

\begin{tabular}{cccccc} 
Time Period & EBITDA/Assets & $\begin{array}{c}\text { Profit } \\
\text { margin }\end{array}$ & $\begin{array}{c}\text { Return on } \\
\text { assets }\end{array}$ & $\begin{array}{c}\text { EBITDA/ } \\
\text { Sales }^{\mathrm{a}}\end{array}$ & $\begin{array}{c}\text { Return on } \\
\text { Equity }\end{array}$ \\
\hline-2 to +1 & -0.0081 & $-0.0398^{* *}$ & -0.0044 & $-0.04625^{*}$ & 0.0054 \\
+1 to +2 & $0.0047^{* *}$ & $0.0197^{*}$ & $0.0063^{* *}$ & 0.0167 & $0.0413^{* *}$ \\
\hline
\end{tabular}

${ }^{a}$ Sales is Compustat item 12, Sales-Net, the same item number as used by Loughran and Ritter (1997). For banks, this item includes total current operating revenue and net pretax profit or loss on securities sold or redeemed. 


\section{Table 8}

\section{Estimation of the Altman, Haldeman, and Narayanan (1977) Model for Recourse Providing and Non-Recourse Providing Credit Card Backed Security Sponsors}

The following table contains estimates of the 7-variable ZETA ${ }^{\mathrm{TM}}$ model of Altman, Haldeman, and Narayanan (1977). The Altman, Haldeman, and Narayanan (1977) variables are: return on assets; the variability of return on assets; the debt service ratio; accumulated profits; liquidity; the market to book ratio of capital; and size of the firm. We include the variables in a probit model of support to analyze their effect on the decision to provide recourse. Recourse providing banks are coded as 1 and non-recourse providing banks are coded as zero. Parameter estimates, chisquare statistics, and p-values associated with the chi-square statistics are reported. $*$ indicates significance at the $10 \%$ level, ** indicates significance at the $5 \%$ level, and $* * *$ indicates significance at the $1 \%$ level.

\begin{tabular}{lrrr}
\hline Variable & Parameter Estimate & Chi-Square & P-Value \\
\hline Intercept & 13.1251 & 2.3956 & 0.1217 \\
ROA & $346.0000^{* *}$ & 4.3617 & 0.0368 \\
SIGMAROA & $-921.0000^{* * *}$ & 10.3285 & 0.0013 \\
DEBTSERV & -0.2253 & 0.0229 & 0.8797 \\
CUMUPROF & -24.9929 & 0.8994 & 0.3429 \\
LIQUID & $8.9241^{* *}$ & 3.8516 & 0.0497 \\
CAPITAL & 0.5308 & 2.0119 & 0.1561 \\
SIZE & $-1.0173^{* *}$ & 4.7297 & 0.0296 \\
Intercept & 13.1251 & 2.3956 & 0.1217 \\
\hline
\end{tabular}


Table 9

Comparison of Issue Attributes Before and After Recourse

The following table contains credit card ABS deal attributes from those deals prior and subsequent to recourse events. All data are from the Securities Data Corp. New Issues Database.

\begin{tabular}{|c|c|c|c|c|c|c|c|c|c|c|}
\hline $\begin{array}{c}\text { Comparison Deals: } \\
\text { Before Support } \\
\text { After Support }\end{array}$ & $\begin{array}{c}\text { Comparison } \\
\text { Deal Issue } \\
\text { Date }\end{array}$ & $\begin{array}{l}\text { A-Class Pool } \\
\text { Size } \\
\text { (\$ thousands) }\end{array}$ & $\begin{array}{l}\text { A-Class } \\
\text { Support }\end{array}$ & $\begin{array}{l}\text { A-Class } \\
\text { Coupon }\end{array}$ & $\begin{array}{l}\text { B-Class Pool } \\
\text { Size } \\
\text { (\$ thousands) }\end{array}$ & $\begin{array}{l}\text { B-Class } \\
\text { Support }\end{array}$ & B-Class Coupon & $\begin{array}{c}\text { Tertiary } \\
\text { Credit } \\
\text { Support }\end{array}$ & $\begin{array}{c}\text { Prior Issue } \\
\text { Frequency }^{a} \\
\text { (days) }\end{array}$ & $\begin{array}{c}\text { Time } \\
\text { Between } \\
\text { Before and } \\
\text { After Issues }\end{array}$ \\
\hline \multicolumn{11}{|l|}{ Sears Roebuck, 19910911} \\
\hline Sears Credit Account Tr 1991-C & 07/11/1991 & 500.0 & $\mathrm{nr}$ & 8.65 & na & na & na & $\mathrm{nr}$ & 75 & 77 \\
\hline Sears Credit Account Tr 1991-D & $09 / 26 / 1991$ & 500.0 & $\mathrm{nr}$ & 7.75 & na & na & na & $\mathrm{nr}$ & & \\
\hline \multicolumn{11}{|l|}{ Sears Roebuck, 19911014} \\
\hline Sears Credit Account Tr 1991-D & 09/26/1991 & 500.0 & $\mathrm{nr}$ & 7.75 & na & na & na & $\mathrm{nr}$ & 75 & 411 \\
\hline Sears Credit Account Master Tr & $11 / 10 / 1992$ & 1000.0 & 0.085 & 5.90 & na & na & na & $\mathrm{nr}$ & & \\
\hline \multicolumn{11}{|l|}{ Citibank NA(Citigroup Inc), $19910513^{\mathrm{b}, \mathrm{d} d}$} \\
\hline Standard Credit Card Tr 1990-7 & 08/20/1990 & 1250.0 & 0.170 & 8.88 & 155.0 & 0.060 & 9.13 & $6 \%$ LOC & 49 & 290 \\
\hline Standard Credit Card Master $\operatorname{Tr}$ & 06/06/1991 & 625.0 & 0.180 & 7.88 & 78.0 & 0.070 & 8.25 & $7 \% \mathrm{CCA}$ & & \\
\hline \multicolumn{11}{|l|}{ Citibank NA(Citigroup Inc), $19930315^{\mathrm{e}}$} \\
\hline Standard Credit Card Master $\operatorname{Tr}$ & $09 / 24 / 1992$ & 1250.0 & 0.110 & 3-M LIBOR +30 & 80.0 & 0.050 & 3-M LIBOR+62.5 & $5 \% \mathrm{CCA}$ & 86 & 336 \\
\hline Standard Credit Card Master Tr & $08 / 26 / 1993$ & 750.0 & 0.110 & 5.95 & 48.0 & 0.050 & 6.15 & $5 \% \mathrm{CCA}$ & & \\
\hline \multicolumn{11}{|l|}{ Household, 19930331} \\
\hline Household Credit Card Tr 1992-1 & 12/22/1992 & 357.0 & 0.160 & 1-M LIBOR +25 & 68.0 & 0.100 & 6.25 & $\mathrm{CCA}$ & 272 & 1,081 \\
\hline Household CC Master Tr 1995-1 & $12 / 08 / 1995$ & 500.0 & 0.125 & 1-M LIBOR+17 & 24.3 & 0.090 & 1-M LIBOR +35 & $9 \%$ CIA & & \\
\hline \multicolumn{11}{|l|}{ Household International Inc, 19951106} \\
\hline Private Label CC Master Tr II 1994-2 & $11 / 09 / 1994$ & 307.5 & 0.180 & 7.80 & 22.5 & 0.120 & 6.70 & $12 \% \mathrm{CIA}$ & 333 & 2,465 \\
\hline Household Private Label CC 2001-1 & 08/09/2001 & 400.0 & 0.156 & 1-M LIBOR+14 & 58.3 & 0.029 & 1-M LIBOR+45 & $15.61 \% \mathrm{OC}$ & & \\
\hline \multicolumn{11}{|l|}{ First Chicago NBD Corp, 19960711} \\
\hline First Chicago Master Tr II 95-P & $06 / 15 / 1995$ & 500.0 & 0.140 & 1-M LIBOR+18 & na & na & na & $\begin{array}{c}12.5 \% \mathrm{CIA} / \\
1 \% \mathrm{CCA}\end{array}$ & 181 & 456 \\
\hline First Chicago Master Tr II 96-Q & $09 / 13 / 1996$ & 900.0 & 0.140 & 1-M LIBOR+13 & na & na & na & $\begin{array}{c}12.5 \% \mathrm{CIA} / \\
1 \% \mathrm{CCA}\end{array}$ & & \\
\hline \multicolumn{11}{|l|}{ AT\&T Corp, $19960909^{\circ}$} \\
\hline AT\&T Universal Master Tr $1996-2$ & 06/24/1996 & 850.0 & 0.156 & 3-M LIBOR+7 & 80.0 & 0.070 & 3-M LIBOR+21 & $7 \%$ CIA & 102 & 317 \\
\hline AT\&T Universal Master Tr 1996-3 & $09 / 10 / 1996$ & 850.0 & 0.156 & 3-M LIBOR +10 & 80.0 & 0.070 & 3-M LIBOR +30 & $7 \% \mathrm{CIA}$ & & \\
\hline AT\&T Universal Master Tr 1997-1 & $05 / 07 / 1997$ & 850.0 & 0.150 & 3-M LIBOR+9 & 80.0 & 0.070 & 3-M LIBOR+28 & $7 \% \mathrm{CIA}$ & & \\
\hline \multicolumn{11}{|l|}{ BANK ONE Corp, 19970305} \\
\hline Banc One Cr Card Master Tr 1996-A & $03 / 20 / 1996$ & 465.0 & 0.170 & 1-W LIBOR+22 & 35.0 & 0.100 & 1-W LIBOR +34.5 & $10 \% \mathrm{CCA}$ & 168 & 490 \\
\hline First USA CC Master $\operatorname{Tr} 1997-5$ & 07/23/1997 & 650.0 & 0.170 & 1-M LIBOR+14 & 58.7 & 0.095 & 1-M LIBOR+33 & $9.5 \%$ CIA & & \\
\hline \multicolumn{11}{|l|}{ Sears Roebuck, $19980518^{\mathrm{c}}$} \\
\hline Sears Credit Account Master Tr 97-1 & 07/21/1997 & 500.0 & 0.115 & 6.20 & 22.5 & 0.070 & 6.40 & $7 \%$ CIA & 108 & 463 \\
\hline Sears Credit Account Master Tr 98-1 & 05/19/1998 & 500.0 & 0.156 & 5.80 & 35.3 & 0.090 & 6.00 & $9 \%$ CIA & & \\
\hline Sears Credit Account Master Tr 98-2 & $10 / 27 / 1998$ & 450.0 & 0.150 & 5.25 & 32.0 & 0.090 & 6.30 & $9 \%$ CIA & & \\
\hline
\end{tabular}

${ }^{a}$ Prior Issue Frequency is the average time between issues for as many as the ten prior issues brought to market. For Household Private Label, we have evidence of only one deal prior to that we use as the "Before" deal.

${ }^{\mathrm{b}}$ The prior Citigroup deal immediately before the recourse event $(1990-8 \mathrm{~B}$, Oct 11, 1990) was a single-tier deal that was not typical of prior issues. We included the next previous multitier deal for comparison instead. Using this deal adds 60 days to the issuance interval between before and after.

${ }^{\mathrm{c}}$ The next deal went to market the day after the recourse event. We included the next deal after that for comparison. This adjustment adds 23 days to the Citi issuance interval between before and after, 239 days to the AT\&T interval, and 161 days to the Sears issuance interval.

${ }^{\mathrm{d}}$ Tertiary credit support obtained from 1990-6, June 21,1990

e The next Citigroup deal immediately after the recourse event (1993-1, August 4, 1993) was a single-tier deal that was not typical of prior or subsequent issues. We included the next multi-tier deal for comparison instead. This adjustment adds 22 days to the issuance interval between before and after.

Note: Mercantile, Prudential and Tandy did not have any other comparison issues before or after the recourse event. First Union's only issues were their 1996-1 and 1996-2, both of which required recourse.

$n a$ indicates data field is not applicable to issue.

$n r$ indicates we were not able to find data relating to a relevant field. 
Table 10

Comparison of Issue Attributes Before and After Recourse, CCISM Firms

The following table contains credit card ABS deal attributes from those deals prior and subsequent to recourse events. All data are from the Securities Data Corp. New Issues Database .

\begin{tabular}{|c|c|c|c|c|c|c|c|c|c|c|}
\hline $\begin{array}{l}\text { Recourse Firm, Recourse Date and } \\
\text { Comparison CCISM Deals }\end{array}$ & $\begin{array}{l}\text { Deal Issue } \\
\text { Date }\end{array}$ & $\begin{array}{c}\text { A-Class Pool } \\
\text { Size } \\
(\$ \text { thou })\end{array}$ & $\begin{array}{l}\text { A-Class } \\
\text { Support }\end{array}$ & $\begin{array}{l}\text { A-Class } \\
\text { Coupon }\end{array}$ & $\begin{array}{c}\text { B-Class Pool } \\
\text { Size } \\
(\$ \text { thou })\end{array}$ & $\begin{array}{l}\text { B-Class } \\
\text { Support }\end{array}$ & $\begin{array}{l}\text { B-Class } \\
\text { Coupon }\end{array}$ & $\begin{array}{c}\text { Tertiary } \\
\text { Credit } \\
\text { Support }\end{array}$ & $\begin{array}{c}\text { Prior Issue } \\
\text { Frequency } \\
\text { (days) }\end{array}$ & $\begin{array}{c}\text { Time } \\
\text { Between } \\
\text { Before and } \\
\text { After Issues }\end{array}$ \\
\hline \multicolumn{11}{|l|}{ Citigroup, 5/13/1991 } \\
\hline Chase Manhattan Cred Tr & $03 / 12 / 1991$ & 750,000 & $\mathrm{nr}$ & $8.45 \%$ & na & na & na & $\mathrm{nr}$ & 88 & 94 \\
\hline Chase Manhattan Cred Tr 1991-1 & $06 / 14 / 1991$ & $1,000,000$ & $11.0 \%$ & $8.75 \%$ & na & na & na & $11 \% \mathrm{CCA}$ & & \\
\hline \multicolumn{11}{|l|}{ Sears, 9/11/1991 } \\
\hline BNY Master Credit Card Trust & $03 / 28 / 1991$ & 750,000 & $13.0 \%$ & $7.95 \%$ & na & na & na & $13 \% \mathrm{CCA}$ & na & 175 \\
\hline BNY Master Credit Card Trust & 09/19/1991 & 600,000 & $13.0 \%$ & $7.10 \%$ & na & na & na & $13 \% \mathrm{CCA}$ & & \\
\hline \multicolumn{11}{|l|}{ Sears, $10 / 14 / 1991$} \\
\hline $\begin{array}{l}\text { BNY Master Credit Card Trust } \\
\text { na }\end{array}$ & 09/19/1991 & $\begin{array}{c}600,000 \\
\text { na }\end{array}$ & $\begin{array}{c}13.0 \% \\
\text { na }\end{array}$ & $\begin{array}{c}7.10 \% \\
\text { na }\end{array}$ & $\begin{array}{l}\text { na } \\
\text { na }\end{array}$ & $\begin{array}{l}\text { na } \\
\text { na }\end{array}$ & $\begin{array}{l}\text { na } \\
\text { na }\end{array}$ & $\begin{array}{c}13 \% \mathrm{CCA} \\
\text { na }\end{array}$ & na & na \\
\hline \multicolumn{11}{|l|}{ Citigroup, 3/15/1993 } \\
\hline Chase Manhattan Credit Card Tr & $02 / 25 / 1992$ & 750,000 & $11.0 \%$ & $7.40 \%$ & na & na & na & $11 \% \mathrm{CCA}$ & 110 & 1107 \\
\hline Chase Manhattan CC Mas Tr 95-1 & 03/08/1995 & 855,000 & $16.0 \%$ & $1 \mathrm{moL}+0.13$ & 50,000 & $11.0 \%$ & $1 \mathrm{moL}+0.285$ & $11 \% \mathrm{CCA}$ & & \\
\hline \multicolumn{11}{|l|}{ Household Int'l, 3/31/1993 } \\
\hline Advanta Credit Card Master Tr & 08/20/1992 & 250,000 & $50.0 \%$ & $5.95 \%$ & 250,000 & $\mathrm{nr}$ & private & $\mathrm{nr}$ & 230 & 342 \\
\hline Advanta Credit Card Master Tr & 07/28/1993 & 400,000 & $53.0 \%$ & $1 \mathrm{moL}+0.23$ & na & na & na & $13 \% \mathrm{CCA}$ & & \\
\hline \multicolumn{11}{|l|}{ Household Int'l, 11/6/1995 } \\
\hline Advanta Crdt Cd Mr Tr 1995-D & 07/19/1995 & 519,000 & $17.5 \%$ & $1 \mathrm{moL}+0.19$ & 30,000 & $11.5 \%$ & $1 \mathrm{moL}+0.32$ & $11.5 \%$ CIA & 178 & 90 \\
\hline Advanta Credit Card Master & $11 / 14 / 1995$ & 801,000 & $13.8 \%$ & $\begin{array}{c}6.05 \% \\
1 \mathrm{moL}+0.19^{\mathrm{a}}\end{array}$ & 44,600 & $7.8 \%$ & $1 \mathrm{moL}+0.30$ & 1. $75 \%$ CIA $2 \%$ CCA & & \\
\hline \multicolumn{11}{|l|}{ First Union, 6/10/1996 } \\
\hline People's Bank CCMT 1995-1 & $03 / 21 / 1995$ & 379,000 & $14.5 \%$ & $1 \mathrm{moL}+0.20$ & 21,000 & $9.0 \%$ & $1 \mathrm{moL}+0.35$ & $9 \% \mathrm{CCA}$ & 145 & 458 \\
\hline People's Bank CCMT 1996-1 & $06 / 21 / 1996$ & 379,000 & $14.5 \%$ & $1 \mathrm{moL}+0.15$ & 21,000 & $9.0 \%$ & $1 \mathrm{moL}+0.30$ & $9 \% \mathrm{CCA}$ & & \\
\hline \multicolumn{11}{|l|}{ First Chicago, 7/11/1996 } \\
\hline Chase Manhattan Credit 1996-3, $4^{\mathrm{b}}$ & $06 / 12 / 1996$ & 957,200 & $14.0 \%$ & $7 \%$ & 42,800 & $8.0 \%$ & $7 \%$ & $8 \%$ CIA & 215 & 257 \\
\hline Chase Manhattan CC Tr 1997-1 & $02 / 24 / 1997$ & $1,150,000$ & $16.0 \%$ & $1 \mathrm{moL}+0.09$ & 95,000 & $9.0 \%$ & $1 \mathrm{moL}+0.29$ & $9 \%$ CIA & & \\
\hline \multicolumn{11}{|l|}{ AT\&T Universal, 9/9/1996 } \\
\hline Capital One Bank Series 1995-3 & $09 / 07 / 1995$ & 840,000 & $20.0 \%$ & $1 \mathrm{moL}+0.15$ & 109,200 & $7.0 \%$ & private & $7 \%$ CIA & 114 & 353 \\
\hline Capital One Master Tr 1996-2 & $11 / 25 / 1996$ & 600,000 & $20.0 \%$ & $1 \mathrm{moL}+0.10$ & 54,000 & $11.0 \%$ & private & $11 \%$ CIA & & \\
\hline \multicolumn{11}{|l|}{ First Union, 2/24/1997 } \\
\hline People's Bank CCMT 1996-1 & $06 / 21 / 1996$ & 379,000 & $14.5 \%$ & $1 \mathrm{moL}+0.15$ & 21,000 & $9.0 \%$ & $1 \mathrm{moL}+0.30$ & $9 \% \mathrm{CCA}$ & 458 & 279 \\
\hline People's Bank CCMT 1997-1 & $03 / 27 / 1997$ & 425,000 & $15.0 \%$ & $1 \mathrm{moL}+0.12$ & 33,750 & $8.3 \%$ & $1 \mathrm{~mL}+0.32$ & $8.25 \%$ CIA & & \\
\hline \multicolumn{11}{|l|}{ Bank One, 3/5/1997 } \\
\hline BA Master CC Trust 1996-A & $07 / 15 / 1996$ & 427,500 & $14.5 \%$ & $1 \mathrm{moL}+13$ & 32,500 & $8.0 \%$ & $1 \mathrm{moL}+26$ & $8 \%$ CIA & na & 325 \\
\hline BankAmerica CCMT 97A & $06 / 05 / 1997$ & 648,800 & $13.5 \%$ & $1 \mathrm{moL}+11$ & 41,300 & $8.0 \%$ & $1 \mathrm{moL}+29$ & $8 \%$ CIA & & \\
\hline \multicolumn{11}{|l|}{ First Union, 5/19/1997 } \\
\hline People's Bank CCMT 1997-1 & 03/27/1997 & 425,000 & $15.0 \%$ & $1 \mathrm{moL}+0.12$ & 33,750 & $8.3 \%$ & $1 \mathrm{~mL}+0.32$ & $8.25 \%$ CIA & 279 & 181 \\
\hline People's Bank CCMT 1997-2 & $09 / 24 / 1997$ & 425000 & $15.0 \%$ & $1 \mathrm{moL}+0.13$ & 33750 & $8.3 \%$ & $1 \mathrm{~mL}+0.33$ & $8.25 \%$ CIA & & \\
\hline \multicolumn{11}{|l|}{ Sears, $5 / 18 / 1998$} \\
\hline MBNA Master CC Trust 1997-N & $11 / 19 / 1997$ & 765,000 & $16.0 \%$ & $3 \mathrm{moL}+7$ & 67,500 & $8.0 \%$ & $3 \mathrm{moL}+23$ & $8 \%$ CIA & 75 & 103 \\
\hline MBNA Master CC Trust 1998-C & 06/10/1998 & 637,500 & $16.0 \%$ & $1 \mathrm{moL}+8$ & 56,250 & $8.0 \%$ & $1 \mathrm{moL}+25$ & $8 \%$ CIA & & \\
\hline
\end{tabular}




\section{Appendix A \\ Long-run Stock Price Performance - Individual Firm Results}

The following appendix contains long-run buy and hold returns for recourse announcing firms, size and book-tomarket equity matched firms, and issue size matched firms. Returns are reported for the year before and the two years after a recourse announcement occurs.

Panel A: Recourse announcing firms

\begin{tabular}{lccc} 
& \multicolumn{3}{c}{ Year relative to recourse announcement } \\
\cline { 2 - 4 } & -1 & 1 & 2 \\
\cline { 2 - 4 } Sears & 0.5712 & 0.0765 & 1.0705 \\
Banc One & 0.3051 & 0.6145 & 0.5622 \\
Tandy & 0.1715 & 0.3816 & 1.1716 \\
AT\&T & 0.0140 & 0.1434 & 0.5378 \\
First Union & 0.3897 & 0.6503 & 1.0784 \\
First Chicago & 0.1744 & 0.7685 & 1.3183 \\
Household & 0.5280 & -0.0721 & 0.4158 \\
Sears & 0.1660 & -0.2293 & -0.3981 \\
Citigroup & -0.2783 & 0.2510 & 0.7837 \\
Mercantile & 0.2431 & 0.3326 & 1.0165 \\
\hline
\end{tabular}

Panel B: Size and book-to-market equity matched firms

\begin{tabular}{lccc}
\hline & \multicolumn{3}{c}{ Year relative to recourse announcement } \\
\cline { 2 - 4 } & -1 & 1 & 2 \\
\cline { 2 - 4 } Wal-Mart & 0.8993 & 0.1963 & -0.0429 \\
FleetBoston & 0.4662 & 0.4060 & 0.4691 \\
Circuit City & 0.7686 & -0.1029 & 0.3440 \\
Verizon & 0.0422 & 0.4225 & 0.6507 \\
KeyCorp & 0.3851 & 0.5408 & 0.9250 \\
BankBoston & 0.2762 & 0.5659 & 1.1517 \\
Beneficial & 0.1303 & 0.0889 & 0.2505 \\
JC Penny & 0.4722 & -0.2543 & -0.7307 \\
Bank of America & 0.3483 & 0.2536 & 0.1901 \\
Compass & 0.2000 & 0.4285 & 1.2610 \\
\hline
\end{tabular}

Panel C: Issue size matched firms

\begin{tabular}{lccc}
\hline & \multicolumn{3}{c}{ Year relative to recourse announcement } \\
\cline { 2 - 4 } & -1 & 1 & 2 \\
\cline { 2 - 4 } Bank of New York & 0.4195 & 0.3920 & 0.7943 \\
Bank of America & 0.6216 & 0.5354 & 0.3431 \\
Charming Shoppes & -0.1515 & -0.3153 & -0.6284 \\
Capital One & 0.1130 & 0.4082 & 2.7069 \\
Peoples Bank & 0.4111 & 0.7847 & 1.4987 \\
Chase & 0.3864 & 0.6194 & 1.2917 \\
Advanta & 0.7338 & 0.3131 & 0.4146 \\
MBNA & 0.6877 & 0.3333 & 0.3611 \\
Chase & -0.1911 & 0.6732 & 0.7797 \\
National City Corp. & 0.2508 & 0.5210 & 1.0269 \\
\hline
\end{tabular}




\section{Appendix B \\ Financial Performance Ratios - Individual Firm Results}

The following appendix contains financial performance ratios for recourse announcing firms, size and book-tomarket equity matched firms, and issue size matched firms. Ratios are reported for the two years before, the two years after and in the year in which a recourse announcement occurs.

Panel A: Financial performance two years prior to recourse announcement

\begin{tabular}{|c|c|c|c|c|c|}
\hline \multicolumn{6}{|c|}{ Recourse announcing firms } \\
\hline & EBITDA/Assets & $\begin{array}{l}\text { Profit } \\
\text { margin }\end{array}$ & $\begin{array}{l}\text { Return on } \\
\text { assets }\end{array}$ & $\begin{array}{l}\text { EBITDA/ } \\
\text { Sales }^{\text {a }}\end{array}$ & Return on Equity \\
\hline Sears & 0.0561 & 0.0280 & 0.0173 & 0.0907 & 0.1107 \\
\hline Banc One & 0.0357 & 0.1424 & 0.0141 & 0.3601 & 0.1608 \\
\hline Tandy & 0.1761 & 0.0420 & 0.0635 & 0.1164 & 0.1062 \\
\hline AT\&T & 0.1657 & 0.0627 & 0.0594 & 0.1749 & 0.2628 \\
\hline First Union & 0.0303 & 0.1414 & 0.0114 & 0.3740 & 0.1638 \\
\hline First Chicago & 0.0253 & 0.1536 & 0.0113 & 0.3440 & 0.1615 \\
\hline Household & 0.0554 & 0.0326 & 0.0050 & 0.3618 & 0.0982 \\
\hline Sears & 0.1154 & 0.0332 & 0.0351 & 0.1091 & 0.2570 \\
\hline Citigroup & 0.0294 & 0.0131 & 0.0022 & 0.1784 & 0.0605 \\
\hline Mercantile & 0.0315 & 0.1574 & 0.0132 & 0.3765 & 0.1507 \\
\hline
\end{tabular}

Size and book-to-market equity matched firms

\begin{tabular}{lccccc}
\hline & EBITDA/Assets & $\begin{array}{l}\text { Profit } \\
\text { margin }\end{array}$ & $\begin{array}{l}\text { Return on } \\
\text { assets }\end{array}$ & $\begin{array}{l}\text { EBITDA/ } \\
\text { Sales }^{\mathrm{a}}\end{array}$ & Return on Equity \\
\cline { 2 - 6 } Wal-Mart & 0.2418 & 0.0405 & 0.1316 & 0.0745 & 0.2783 \\
FleetBoston & 0.0339 & 0.0775 & 0.0072 & 0.3634 & 0.1022 \\
Circuit City & 0.1514 & 0.0013 & 0.0036 & 0.0559 & 0.0086 \\
Verizon & 0.2291 & -0.0547 & -0.0311 & 0.4032 & -0.1241 \\
KeyCorp & 0.0302 & 0.1589 & 0.0128 & 0.3752 & 0.1881 \\
BankBoston & 0.0275 & 0.0958 & 0.0098 & 0.2697 & 0.1653 \\
Beneficial & 0.0980 & 0.0822 & 0.0149 & 0.5401 & 0.1310 \\
JC Penny & 0.1163 & 0.0380 & 0.0490 & 0.0902 & 0.1521 \\
Bank of America & 0.0241 & 0.0968 & 0.0112 & 0.2087 & 0.2249 \\
Compass & 0.0261 & 0.1503 & 0.0109 & 0.3591 & 0.1659 \\
\hline
\end{tabular}

Issue size matched firms

\begin{tabular}{lccccc}
\hline & EBITDA/Assets & $\begin{array}{l}\text { Profit } \\
\text { margin }\end{array}$ & $\begin{array}{l}\text { Return on } \\
\text { assets }\end{array}$ & $\begin{array}{l}\text { EBITDA/ } \\
\text { Sales }^{\mathrm{a}}\end{array}$ & Return on Equity \\
\cline { 2 - 6 } Bank of New York & 0.0085 & 0.0092 & 0.0010 & 0.0751 & 0.0214 \\
Bank of America & 0.0256 & 0.1194 & 0.0104 & 0.2933 & 0.1528 \\
Charming Shoppes & 0.1516 & 0.0455 & 0.0768 & 0.0898 & 0.1348 \\
Capital One & 0.0981 & 0.1453 & 0.0308 & 0.4626 & 0.2007 \\
Peoples Bank & 0.0255 & 0.1346 & 0.0108 & 0.3179 & 0.1608 \\
Chase & 0.0273 & 0.1077 & 0.0106 & 0.2787 & 0.1732 \\
Advanta & 0.0369 & 0.0832 & 0.0147 & 0.2093 & 0.2135 \\
MBNA & 0.0858 & 0.1447 & 0.0279 & 0.4455 & 0.2784 \\
Chase & 0.0068 & -0.0478 & -0.0062 & 0.0529 & -0.1621 \\
National City Corp. & 0.0369 & 0.1478 & 0.0134 & 0.4074 & 0.1779 \\
\hline
\end{tabular}


Panel B: Financial performance one year prior to recourse announcement

Recourse announcing firms

\begin{tabular}{lccccc}
\hline & EBITDA/Assets & $\begin{array}{l}\text { Profit } \\
\text { margin }\end{array}$ & $\begin{array}{l}\text { Return on } \\
\text { assets }\end{array}$ & $\begin{array}{l}\text { EBITDA/ } \\
\text { Sales }^{\mathrm{a}}\end{array}$ & Return on Equity \\
\cline { 2 - 5 } Sears & 0.0433 & 0.0161 & 0.0094 & 0.0744 & 0.0704 \\
Banc One & 0.0357 & 0.1389 & 0.0140 & 0.3536 & 0.1690 \\
Tandy & 0.1353 & 0.0388 & 0.0581 & 0.0903 & 0.1237 \\
AT\&T & 0.1682 & 0.0017 & 0.0016 & 0.1878 & 0.0080 \\
First Union & 0.0279 & 0.1351 & 0.0108 & 0.3474 & 0.1614 \\
First Chicago & 0.0256 & 0.1077 & 0.0094 & 0.2921 & 0.1445 \\
Household & 0.0453 & 0.0457 & 0.0061 & 0.3376 & 0.1187 \\
Sears & 0.1199 & 0.0288 & 0.0307 & 0.1124 & 0.2027 \\
Citigroup & 0.0312 & 0.0119 & 0.0021 & 0.1762 & 0.0559 \\
Mercantile & 0.0296 & 0.1551 & 0.0136 & 0.3378 & 0.1508 \\
\hline
\end{tabular}

Size and book-to-market equity matched firms

\begin{tabular}{lccccc}
\hline & EBITDA/Assets & $\begin{array}{l}\text { Profit } \\
\text { margin }\end{array}$ & $\begin{array}{l}\text { Return on } \\
\text { assets }\end{array}$ & $\begin{array}{l}\text { EBITDA/ } \\
\text { Sales }^{\mathrm{a}}\end{array}$ & Return on Equity \\
\cline { 2 - 5 } Wal-Mart & 0.2367 & 0.0417 & 0.1312 & 0.0752 & 0.2713 \\
FleetBoston & 0.0378 & 0.1416 & 0.0133 & 0.4021 & 0.1763 \\
Circuit City & 0.1689 & 0.0280 & 0.0783 & 0.0605 & 0.1746 \\
Verizon & 0.2369 & 0.1384 & 0.0769 & 0.4262 & 0.2780 \\
KeyCorp & 0.0299 & 0.1363 & 0.0124 & 0.3271 & 0.1652 \\
BankBoston & 0.0289 & 0.1014 & 0.0114 & 0.2568 & 0.1668 \\
Beneficial & 0.0816 & 0.0249 & 0.0040 & 0.5123 & 0.0415 \\
JC Penny & 0.0907 & 0.0233 & 0.0256 & 0.0825 & 0.1022 \\
Bank of America & 0.0221 & 0.0905 & 0.0101 & 0.1987 & 0.1920 \\
Compass & 0.0264 & 0.1299 & 0.0107 & 0.3187 & 0.1560 \\
\hline
\end{tabular}

Issue size matched firms

\begin{tabular}{lccccc}
\hline & EBITDA/Assets & $\begin{array}{l}\text { Profit } \\
\text { margin }\end{array}$ & $\begin{array}{l}\text { Return on } \\
\text { assets }\end{array}$ & $\begin{array}{l}\text { EBITDA/ } \\
\text { Sales }^{\mathrm{a}}\end{array}$ & Return on Equity \\
\cline { 2 - 6 } Bank of New York & 0.0195 & 0.0578 & 0.0068 & 0.1662 & 0.1238 \\
Bank of America & 0.0309 & 0.1356 & 0.0128 & 0.3274 & 0.1748 \\
Charming Shoppes & 0.1710 & 0.0571 & 0.0915 & 0.1068 & 0.1610 \\
Capital One & 0.0906 & 0.1252 & 0.0266 & 0.4265 & 0.2111 \\
Peoples Bank & 0.0280 & 0.1168 & 0.0103 & 0.3165 & 0.1330 \\
Chase & 0.0158 & 0.1126 & 0.0098 & 0.1825 & 0.1633 \\
Advanta & 0.0537 & 0.1405 & 0.0271 & 0.2791 & 0.2763 \\
MBNA & 0.0948 & 0.1376 & 0.0292 & 0.4463 & 0.3160 \\
Chase & 0.0135 & -0.0244 & -0.0034 & 0.0971 & -0.0859 \\
National City Corp. & 0.0350 & 0.1348 & 0.0128 & 0.3670 & 0.1700 \\
\hline
\end{tabular}


Panel C: Financial performance in the year of a recourse announcement

Recourse announcing firms

\begin{tabular}{lccccc}
\hline & EBITDA/Assets & $\begin{array}{l}\text { Profit } \\
\text { margin }\end{array}$ & $\begin{array}{l}\text { Return on } \\
\text { assets }\end{array}$ & $\begin{array}{l}\text { EBITDA/ } \\
\text { Sales }^{\mathrm{a}}\end{array}$ & Return on Equity \\
\cline { 2 - 6 } Sears & 0.0431 & 0.0223 & 0.0120 & 0.0801 & 0.0923 \\
Banc One & 0.0418 & 0.0988 & 0.0113 & 0.3667 & 0.1275 \\
Tandy & 0.1355 & 0.0233 & 0.0301 & 0.1049 & 0.0649 \\
AT\&T & 0.2150 & 0.1132 & 0.1064 & 0.2288 & 0.2911 \\
First Union & 0.0286 & 0.1251 & 0.0107 & 0.3349 & 0.1498 \\
First Chicago & 0.0310 & 0.1419 & 0.0137 & 0.3203 & 0.1677 \\
Household & 0.0462 & 0.0671 & 0.0091 & 0.3417 & 0.1437 \\
Sears & 0.1193 & 0.0254 & 0.0280 & 0.1079 & 0.1728 \\
Citigroup & 0.0279 & -0.0144 & -0.0021 & 0.1900 & -0.0622 \\
Mercantile & 0.0274 & 0.1184 & 0.0101 & 0.3211 & 0.1175 \\
\hline
\end{tabular}

Size and book-to-market equity matched firms

\begin{tabular}{lccccc}
\hline & EBITDA/Assets & $\begin{array}{l}\text { Profit } \\
\text { margin }\end{array}$ & $\begin{array}{l}\text { Return on } \\
\text { assets }\end{array}$ & $\begin{array}{l}\text { EBITDA/ } \\
\text { Sales }^{\mathrm{a}}\end{array}$ & Return on Equity \\
\cline { 2 - 6 } Wal-Mart & 0.2010 & 0.0396 & 0.1134 & 0.0702 & 0.2406 \\
FleetBoston & 0.0398 & 0.1610 & 0.0152 & 0.4206 & 0.1774 \\
Circuit City & 0.1748 & 0.0337 & 0.0873 & 0.0675 & 0.1916 \\
Verizon & 0.2229 & 0.1438 & 0.0757 & 0.4235 & 0.2535 \\
KeyCorp & 0.0301 & 0.1297 & 0.0116 & 0.3374 & 0.1604 \\
BankBoston & 0.0310 & 0.1042 & 0.0104 & 0.3101 & 0.1469 \\
Beneficial & 0.0766 & 0.0936 & 0.0142 & 0.5053 & 0.1530 \\
JC Penny & 0.1063 & 0.0181 & 0.0241 & 0.0800 & 0.0823 \\
Bank of America & 0.0264 & 0.0916 & 0.0097 & 0.2488 & 0.1668 \\
Compass & 0.0267 & 0.1322 & 0.0109 & 0.3231 & 0.1605 \\
\hline
\end{tabular}

Issue size matched firms

\begin{tabular}{lccccc}
\hline & EBITDA/Assets & $\begin{array}{l}\text { Profit } \\
\text { margin }\end{array}$ & $\begin{array}{l}\text { Return on } \\
\text { assets }\end{array}$ & $\begin{array}{l}\text { EBITDA/ } \\
\text { Sales }^{\mathrm{a}}\end{array}$ & Return on Equity \\
\cline { 2 - 6 } Bank of New York & 0.0162 & 0.0289 & 0.0031 & 0.1515 & 0.0487 \\
Bank of America & 0.0279 & 0.1416 & 0.0116 & 0.3392 & 0.1446 \\
Charming Shoppes & 0.1933 & 0.0688 & 0.1100 & 0.1209 & 0.1822 \\
Capital One & 0.0818 & 0.1090 & 0.0240 & 0.3716 & 0.2097 \\
Peoples Bank & 0.0252 & 0.1220 & 0.0105 & 0.2934 & 0.1296 \\
Chase & 0.0113 & 0.1237 & 0.0073 & 0.1915 & 0.1345 \\
Advanta & 0.0630 & 0.2056 & 0.0372 & 0.3480 & 0.2331 \\
MBNA & 0.0891 & 0.1494 & 0.0301 & 0.4426 & 0.3247 \\
Chase & 0.0194 & 0.0439 & 0.0053 & 0.1606 & 0.1214 \\
National City Corp. & 0.0369 & 0.1495 & 0.0145 & 0.3811 & 0.1662 \\
\hline
\end{tabular}


Panel D: Financial performance one year after a recourse announcement

Recourse announcing firms

\begin{tabular}{lccccc}
\hline & EBITDA/Assets & $\begin{array}{l}\text { Profit } \\
\text { margin }\end{array}$ & $\begin{array}{l}\text { Return on } \\
\text { assets }\end{array}$ & $\begin{array}{l}\text { EBITDA/ } \\
\text { Sales }^{\mathrm{a}}\end{array}$ & Return on Equity \\
\cline { 2 - 6 } Sears & 0.0288 & -0.0751 & -0.0471 & 0.0460 & -0.4269 \\
Banc One & 0.0383 & 0.1214 & 0.0119 & 0.3910 & 0.1526 \\
Tandy & 0.1357 & 0.0450 & 0.0692 & 0.0882 & 0.1623 \\
AT\&T & 0.1841 & 0.0907 & 0.0791 & 0.2111 & 0.2048 \\
First Union & 0.0296 & 0.1323 & 0.0121 & 0.3251 & 0.1576 \\
First Chicago & 0.0297 & 0.1510 & 0.0134 & 0.3355 & 0.1963 \\
Household & 0.0496 & 0.0799 & 0.0107 & 0.3698 & 0.1671 \\
Sears & 0.1237 & 0.0354 & 0.0393 & 0.1113 & 0.2108 \\
Citigroup & 0.0319 & 0.0226 & 0.0034 & 0.2137 & 0.0906 \\
Mercantile & 0.0229 & 0.0907 & 0.0068 & 0.3041 & 0.0849 \\
\hline
\end{tabular}

Size and book-to-market equity matched firms

\begin{tabular}{lccccc}
\hline & EBITDA/Assets & $\begin{array}{l}\text { Profit } \\
\text { margin }\end{array}$ & $\begin{array}{l}\text { Return on } \\
\text { assets }\end{array}$ & $\begin{array}{l}\text { EBITDA/ } \\
\text { Sales }^{\mathrm{a}}\end{array}$ & Return on Equity \\
\cline { 2 - 5 } Wal-Mart & 0.1871 & 0.0367 & 0.1042 & 0.0658 & 0.2301 \\
FleetBoston & 0.0393 & 0.1532 & 0.0147 & 0.4103 & 0.1757 \\
Circuit City & 0.1729 & 0.0321 & 0.0852 & 0.0651 & 0.1864 \\
Verizon & 0.2397 & 0.0808 & 0.0455 & 0.4259 & 0.1920 \\
KeyCorp & 0.0299 & 0.1399 & 0.0125 & 0.3350 & 0.1774 \\
BankBoston & 0.0312 & 0.1307 & 0.0127 & 0.3215 & 0.2029 \\
Beneficial & 0.0750 & 0.0831 & 0.0124 & 0.5047 & 0.1382 \\
JC Penny & 0.0912 & 0.0189 & 0.0251 & 0.0687 & 0.0887 \\
Bank of America & 0.0290 & 0.0978 & 0.0083 & 0.3435 & 0.1193 \\
Compass & 0.0270 & 0.1376 & 0.0116 & 0.3216 & 0.1620 \\
\hline
\end{tabular}

Issue size matched firms

\begin{tabular}{lccccc}
\hline & EBITDA/Assets & $\begin{array}{l}\text { Profit } \\
\text { margin }\end{array}$ & $\begin{array}{l}\text { Return on } \\
\text { assets }\end{array}$ & $\begin{array}{l}\text { EBITDA/ } \\
\text { Sales }^{\mathrm{a}}\end{array}$ & Return on Equity \\
\cline { 2 - 6 } Bank of New York & 0.0251 & 0.1030 & 0.0090 & 0.2864 & 0.1185 \\
Bank of America & 0.0261 & 0.0997 & 0.0084 & 0.3113 & 0.1125 \\
Charming Shoppes & 0.1705 & 0.0636 & 0.0962 & 0.1127 & 0.1528 \\
Capital One & 0.0911 & 0.1060 & 0.0268 & 0.3609 & 0.2120 \\
Peoples Bank & 0.0326 & 0.1193 & 0.0113 & 0.3445 & 0.1303 \\
Chase & 0.0162 & 0.1697 & 0.0101 & 0.2705 & 0.1854 \\
Advanta & 0.0595 & 0.2014 & 0.0341 & 0.3519 & 0.2407 \\
MBNA & 0.1025 & 0.1583 & 0.0332 & 0.4889 & 0.2439 \\
Chase & 0.0227 & 0.0574 & 0.0067 & 0.1960 & 0.1269 \\
National City Corp. & 0.0350 & 0.1567 & 0.0148 & 0.3715 & 0.1886 \\
\hline
\end{tabular}


Panel E: Financial performance two years after a recourse announcement

\begin{tabular}{lccccc}
\hline \multicolumn{7}{c}{ Recourse announcing firms } \\
\hline Sears & EBITDA/Assets & $\begin{array}{l}\text { Profit } \\
\text { margin }\end{array}$ & $\begin{array}{l}\text { Return on } \\
\text { assets }\end{array}$ & $\begin{array}{l}\text { EBITDA/ } \\
\text { Sales }^{\mathrm{a}}\end{array}$ & Return on Equity \\
\cline { 2 - 6 } Banc One & 0.0397 & 0.0467 & 0.0261 & 0.0709 & 0.2350 \\
Tandy & 0.0380 & 0.1365 & 0.0130 & 0.3990 & 0.1757 \\
AT\&T & 0.1634 & 0.0362 & 0.0778 & 0.0759 & 0.1361 \\
First Union & 0.2510 & 0.1202 & 0.1074 & 0.2809 & 0.2507 \\
First Chicago & 0.0320 & 0.1342 & 0.0122 & 0.3531 & 0.1683 \\
Household & 0.0757 & 0.0881 & 0.0155 & 0.4299 & 0.1684 \\
Sears & 0.1223 & 0.0328 & 0.0364 & 0.1102 & 0.1984 \\
Citigroup & 0.0398 & 0.0689 & 0.0102 & 0.2680 & 0.2204 \\
Mercantile & 0.0264 & 0.1279 & 0.0105 & 0.3226 & 0.1221 \\
\hline
\end{tabular}

Size and book-to-market equity matched firms

\begin{tabular}{lccccc}
\hline & EBITDA/Assets & $\begin{array}{l}\text { Profit } \\
\text { margin }\end{array}$ & $\begin{array}{l}\text { Return on } \\
\text { assets }\end{array}$ & $\begin{array}{l}\text { EBITDA/ } \\
\text { Sales }^{\mathrm{a}}\end{array}$ & Return on Equity \\
\cline { 2 - 6 } Wal-Mart & 0.1758 & 0.0360 & 0.0970 & 0.0652 & 0.2277 \\
FleetBoston & 0.0370 & 0.1020 & 0.0107 & 0.3530 & 0.1394 \\
Circuit City & 0.1724 & 0.0301 & 0.0838 & 0.0619 & 0.1913 \\
Verizon & 0.2517 & 0.0939 & 0.0538 & 0.4397 & 0.2276 \\
KeyCorp & 0.0295 & 0.1403 & 0.0124 & 0.3324 & 0.1615 \\
BankBoston & \multicolumn{5}{c}{ Data for First Chicago not available } \\
Beneficial & 0.0733 & 0.0628 & 0.0096 & 0.4801 & 0.1084 \\
JC Penny & 0.0805 & 0.0103 & 0.0161 & 0.0517 & 0.0495 \\
Bank of America & 0.0329 & 0.1229 & 0.0105 & 0.3873 & 0.1379 \\
Compass & 0.0254 & 0.1333 & 0.0105 & 0.3241 & 0.1549 \\
\hline
\end{tabular}

Issue size matched firms

\begin{tabular}{lccccc}
\hline & EBITDA/Assets & $\begin{array}{l}\text { Profit } \\
\text { margin }\end{array}$ & $\begin{array}{l}\text { Return on } \\
\text { assets }\end{array}$ & $\begin{array}{l}\text { EBITDA/ } \\
\text { Sales }^{\mathrm{a}}\end{array}$ & Return on Equity \\
\cline { 2 - 6 } Bank of New York & 0.0312 & 0.1472 & 0.0123 & 0.3744 & 0.1480 \\
Bank of America & 0.0290 & 0.1530 & 0.0125 & 0.3559 & 0.1777 \\
Charming Shoppes & 0.1166 & 0.0351 & 0.0532 & 0.0770 & 0.0800 \\
Capital One & 0.0965 & 0.1059 & 0.0292 & 0.3498 & 0.2166 \\
Peoples Bank & 0.0331 & 0.1015 & 0.0092 & 0.3632 & 0.1076 \\
Chase & \multicolumn{7}{c}{ Data for First Chicago not available } & \\
Advanta & 0.0546 & 0.1916 & 0.0302 & 0.3466 & 0.2034 \\
MBNA & 0.1013 & 0.1668 & 0.0339 & 0.4978 & 0.1981 \\
Chase & 0.0239 & 0.0848 & 0.0095 & 0.2145 & 0.1437 \\
National City Corp. & 0.0342 & 0.1327 & 0.0121 & 0.3735 & 0.1535 \\
\hline
\end{tabular}

${ }^{\text {a }}$ Sales is Compustat item 12, Sales-Net, the same item number used by Loughran and Ritter (1997). For banks, this item includes total current operating revenue and net pretax profit or loss on securities sold or redeemed. 